\title{
An Innovative Solar-Biomass Energy System to Increase the Share of Renewables in Office Buildings
}

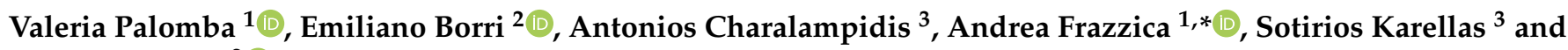 \\ Luisa F. Cabeza ${ }^{2}$ (D) \\ 1 CNR Institute for Advanced Energy Technologies (ITAE), 98126 Messina, Italy; valeria.palomba@itae.cnr.it \\ 2 GREiA Research Group, Universitat de Lleida, Pere de Cabrera s/n, 25001 Lleida, Spain; \\ emiliano.borri@udl.cat (E.B.); luisaf.cabeza@udl.cat (L.F.C.) \\ 3 Laboratory of Steam Boilers and Thermal Plants, National Technical University of Athens, \\ 15780 Athens, Greece; antonishar@mail.ntua.gr (A.C.); sotokar@mail.ntua.gr (S.K.) \\ * Correspondence: andrea.frazzica@itae.cnr.it
}

Citation: Palomba, V.; Borri, E.; Charalampidis, A.; Frazzica, A.; Karellas, S.; Cabeza, L.F. An Innovative Solar-Biomass Energy System to Increase the Share of Renewables in Office Buildings. Energies 2021, 14, 914. https:// doi.org/10.3390/en14040914

Academic Editor: Chi-Ming Lai Received: 2 January 2021

Accepted: 4 February 2021

Published: 9 February 2021

Publisher's Note: MDPI stays neutral with regard to jurisdictional claims in published maps and institutional affiliations.

Copyright: (c) 2021 by the authors. Licensee MDPI, Basel, Switzerland. This article is an open access article distributed under the terms and conditions of the Creative Commons Attribution (CC BY) license (https:/ / creativecommons.org/licenses/by/ $4.0 /)$.

\begin{abstract}
Increasing the energy efficiency of residential and non-residential buildings is a crucial point towards the development of the sustainable cities of the future. To reach such a goal, the commonly employed intervention measures (for instance, on facades and glass) are not sufficient and efforts in reaching a fully renewable energy generation are mandatory. In this context, this paper discusses the applicability of a system with solar and biomass as the main energy sources in different climates for heating, cooling, domestic hot water and electricity generation in office buildings. The energy system includes solar thermal collectors with thermoelectric generators, a biomass boiler, a reversible heat pump/organic Rankine cycle and an adsorption chiller. The results showed that the system can operate with a share of renewables higher than $70 \%$ for all energy needs, with up to $80 \%$ of the overall energy demand supplied only by solar and biomass sources even in the northern locations.
\end{abstract}

Keywords: energy generation; renewable energy; efficient buildings

\section{Introduction}

Energy efficiency in the building sector is a central topic both for policymakers and international institutions in the field of research [1]. In the European Union (EU), all new buildings starting from 2021 must comply with Nearly Zero Energy Building (NZEB) standards; such an obligation has already been in force since 2019 for public buildings as per the Energy Performance of Buildings Directive [2]. In addition, other directives on energy efficiency [3] and renewable energies [4] endorse all countries to improve their building stocks through initiatives and specific funding. Such a tendency towards more sustainable and efficient buildings, both residential and tertiary ones, were recently supported and promoted by the European Green Deal [5].

Increasing the energy efficiency of buildings and their self-consumption brings other benefits to the overall energy system such as the reduction of the electricity demand in peak hours and a better management of the grid as reported by Jradi et al. [6]. To this aim, several solutions have been proposed that include photovoltaic (PV) systems, thermo-photovoltaic (PV-T) for electricity and thermal generation and co-generation and tri-generation using gas, solar or biomass as the main driver, fuel cells and Stirling engines, investigated for instance by Calise et al. and Seddiki and Bennadji [7,8]. However, the implementation and optimization of systems that include two or more energy sources to provide heating, cooling, domestic hot water (DHW) and electricity at the same time are still in their early stages and require further efforts in the definition of the best strategies and solutions for each type of building $[9,10]$. The vast majority of works in the literature relate to residential buildings for which extensive reviews on different existing alternatives can be found $[1,11]$. 
On the contrary, non-residential tertiary buildings especially public buildings and offices have only recently gained more attention despite their high energy consumption and the need for specific measures, as stated for instance in the EU Energy Efficiency Directive [3]. Among the solutions proposed for increasing the energy efficiency of such buildings, the intervention and retrofitting of facades and windows are the most common as it has been demonstrated that they can reduce by $20-30 \%$ the energy consumption of the building $[12,13]$. However, it has been proven that recommended management strategies based on passive measures including shading and the reduction of daylight bring about a reduction of visual and thermal comfort as highlighted by Ballarin et al. [14], thus needing caution in the application. Indeed, adding shading devices reduces the amount of light indoors, which can negatively affect productivity in the workspace. In addition, in order to move towards the NZEB standard such interventions are not sufficient and must be complemented with a renewable-driven energy system [14,15]. A methodology for such an assessment was proposed for sub-tropical climates by Melgar et al. [16] and it is based on the evaluation of the energy demand of the building and the calculation of the energy produced by each generator.

Among the available analyses specifically devoted to office buildings, the use of water produced in the surroundings is exploited by Park et al. [17] for heating, cooling and DHW production, with a related reduction in energy consumption of the examined buildings in the range of $8-27 \%$ and a reduction in $\mathrm{CO}_{2}$ emissions of $40 \%$. Another solution based on a multi-generation system including PV-T collectors and a ground-source heat pump is presented by Bae et al. [18] for reaching the Zero Energy Building (ZEB) standard in Canadian and South Korean climates. The energy savings estimated were about $60 \%$ with a reduction in the bill up to $130 \%$ annually thus also showing the economic feasibility of such solutions. In Braun et al. [19], a solution with PV-T collectors as a generation source for heating and electricity coupled with a reversible heat pump was reported. The results showed that high solar fractions and primary energy savings could be achieved if the utilization of generation sources for covering all of the energy demand of the office (heating, cooling, ventilation and electricity) was exploited. In addition, an economic analysis was carried out and proved that the costs for such a system were comparable with conventional solar thermal and solar electrical cooling systems. In Mohamed et al. [20], different multi-generation systems for co-generation and tri-generation applied to an office building in Helsinki were evaluated. The results of [20] showed that co-generation systems based on biomass were the most cost-effective alternative whereas, from an energy point of view, the tri-generation biomass system was the desirable option.

From this context, it is clear that there is yet to be a systematic and wide assessment on multi-generation systems for office buildings especially for what concerns the increase of the share of renewables. Accordingly, within the SolBio-Rev project, an integrated system for supplying the different thermal and electricity demands of an office building was developed, which relied mainly on solar and biomass energy as sources. The system's architecture and its application to residential buildings were recently published [21], showing the possibility of supporting a strong increase of the share of renewables in residential buildings across Europe. In this paper, the evaluation of the potentialities of this system for providing heating, cooling, DHW and electricity in office buildings in three different climates (Madrid, Berlin, Helsinki) is presented. The energy flows for the different cases are presented and the possibility of reaching $100 \%$ renewables is discussed. Indeed, the presented analysis differs from the common literature because it is not focused on giving rigorous dynamic information on the investigated buildings but rather presents a critical analysis on the perspective of polygeneration systems towards the contribution to the decarbonization of the building stock.

\section{The SolBio-Rev Multi-Generation System System Description}

The main components of the solar-biomass-sourced system are [21]: 
- $\quad$ evacuated tube solar thermal collectors with thermoelectric generators (TEGs);

- a reversible heat pump/Organic Rankine Cycle (ORC);

- an adsorption chiller;

- a biomass boiler.

In addition, a storage tank is used to store the heat from the evacuated tube collectors and a small buffer tank is connected on the evaporator side of the heat pump for peak shaving in the heating/cooling demand. The block diagram of the system including its main components and the direction of energy flows is shown in Figure 1. Solar thermal collectors supply heat to the storage tank for DHW and space heating or for driving the adsorption module and the ORC. In addition, if the thermal fluid is passed through the TEG block, electricity can be produced. The biomass boiler, similarly, can be used for direct supply the storage tank for DHW and heating or for driving the ORC with high efficiency thanks to the higher temperatures that can be reached (i.e., $120^{\circ} \mathrm{C}$, using a pressurized water circuit). The reversible heat pump/ORC can work in two modes, space heating/cooling (heat pump mode) or for the generation of electricity (ORC mode). In the heat pump winter operation, either low temperature heat from solar collectors (at $15^{\circ} \mathrm{C}$ ) or ambient heat constitute the evaporation source of the heat pump. In summer mode, the evaporator of the adsorption module can be connected to the condenser of the heat pump that can work at a lower temperature level instead thus achieving a higher efficiency and reducing the electric consumption by up to $40 \%$ compared with a water source heat pump [22,23]. A dry cooler is used to source ambient heat during winter for the operation of the heat pump and to serve as a sink during summer for the adsorption heat and the condensation heat of the ORC.

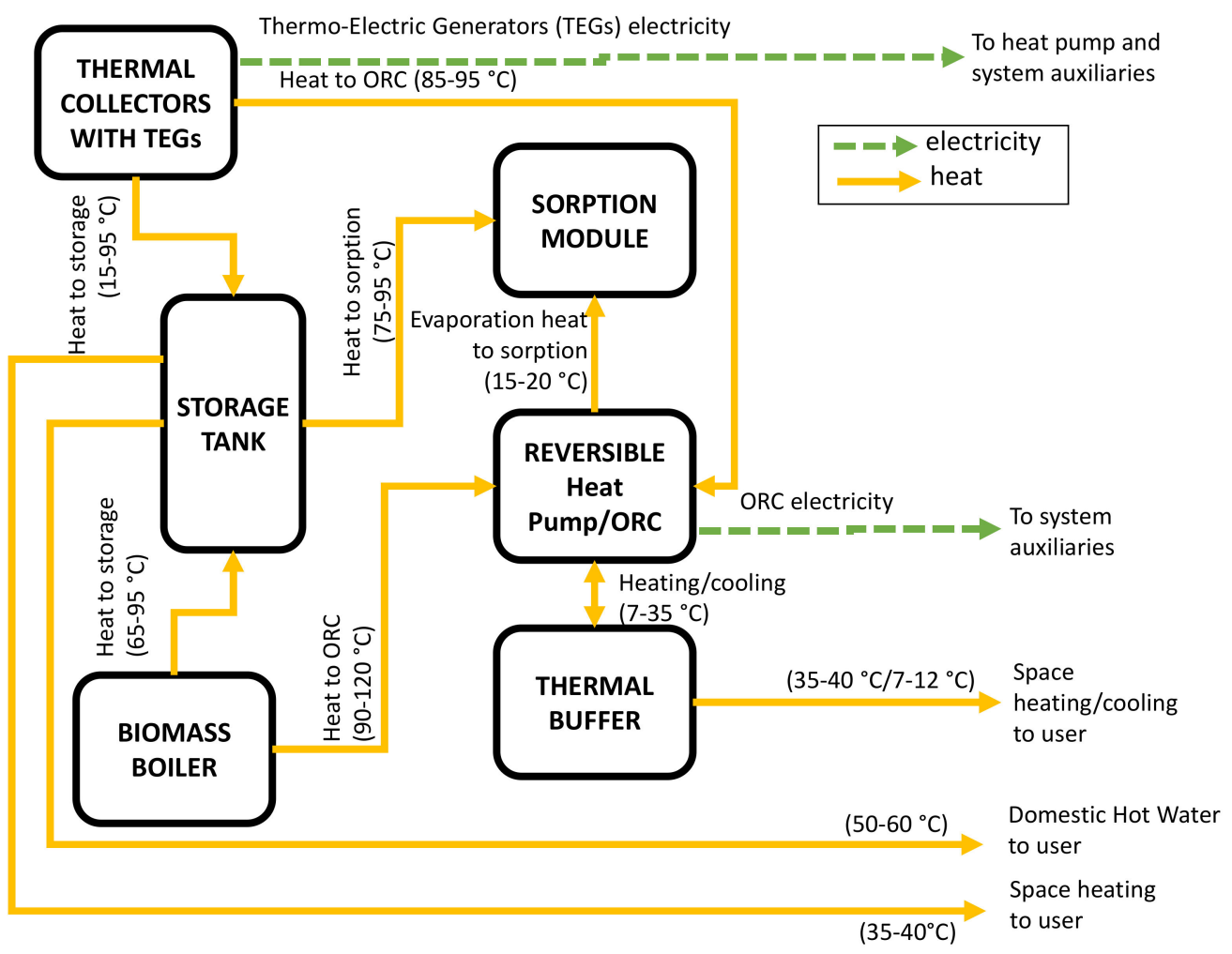

Figure 1. Block diagram of the multi-generation system including the main energy flows.

The system is designed to operate with a fan coil distribution and therefore the temperature levels for operation in the winter (space heating) and the summer (space cooling) are $35-40{ }^{\circ} \mathrm{C}$ and $7-12{ }^{\circ} \mathrm{C}$, respectively. In addition, the temperature level for DHW was considered to be $50-60^{\circ} \mathrm{C}$. It is worth noticing that due to the fact that the storage tank is always connected to the solar collectors and the biomass boiler it is considered that its 
temperature can always be controlled in order to avoid any issue regarding, for example, the growth of legionella [24].

\section{Operating Modes}

The different sections of the analyzed multi-generation system can be managed in multiple ways according to building requirements, climate and season. Indeed, the development of optimized control strategies will be the focus of future activities. In the following the main operating modes are presented, which consider only basic control strategies to serve as the starting point for the present evaluation of the system potentiality in different climates. The main feature that differentiates the installation in warmer climates (where the cooling demand during summer season is relevant and the ambient temperature is high) from the colder climates (with limited cooling demand in the summer) is the presence of the adsorption module. Such a difference is considered in the following operating modes.

- Winter operation:

DHW can be directly produced from solar heat if the temperature level of the solar collectors is higher than $45^{\circ} \mathrm{C}$ or by the biomass boiler.

Space heating can be achieved from solar heat (if there is no need for DHW or if the temperature in the storage tank is lower than the $65^{\circ} \mathrm{C}$ needed for DHW but higher than $35^{\circ} \mathrm{C}$ ) otherwise by the heat pump or the biomass boiler. The heat pump can work in dual source mode using either ambient heat as an evaporation source or low temperature solar heat $\left(15-20^{\circ} \mathrm{C}\right)$.

Electricity is mainly sourced from the grid. However, if the biomass boiler and the heat pump are not needed to supply thermal power for space heating, a biomass-driven ORC operation is possible and, therefore, the electricity can be produced by the ORC. Alternatively, if the temperature level from the solar collectors is enough for driving the TEGs $\left(50-60{ }^{\circ} \mathrm{C}\right)$, this component can be used for this purpose.

- Summer operation:

DHW is mainly produced from solar heat.

Space cooling is produced by the reversible heat pump either as a stand-alone component (colder climates) or as a cascade system with the sorption chiller (warmer climates). In this latter case, the evaporator of the adsorption module is connected to the compressor of the heat pump to reduce the temperature lift and therefore increase the efficiency of the heat pump.

Electricity is mainly sourced from the grid. In colder climates, if there is no cooling demand the electricity can be supplied also by the ORC using solar heat as the driver. If the temperature level is not enough to drive the ORC, solar thermal fluid can be passed through the TEGs thus exploiting them for the electricity supply.

- Intermediate seasons:

DHW is directly supplied by solar heat with the biomass boiler working as a backup unit.

Space heating demand is covered either by solar thermal collectors or the dual source heat pump mode.

Electricity can be provided by TEGs or the ORC. The main heat source for the ORC is the biomass boiler (in colder climates) or solar heat (in warmer climates).

\section{Methodology and Main Assumptions}

The methodology followed for the evaluation of the potentiality of the multi-generation system proposed is schematically presented in Figure 2. The main focus of the study was the energy analysis and the results are presented in the next sections. The primary goal of the analysis was to assess whether the potentiality exists to reach a high share of renewables (i.e., up to $100 \%$ ) with the solar-biomass system proposed. 


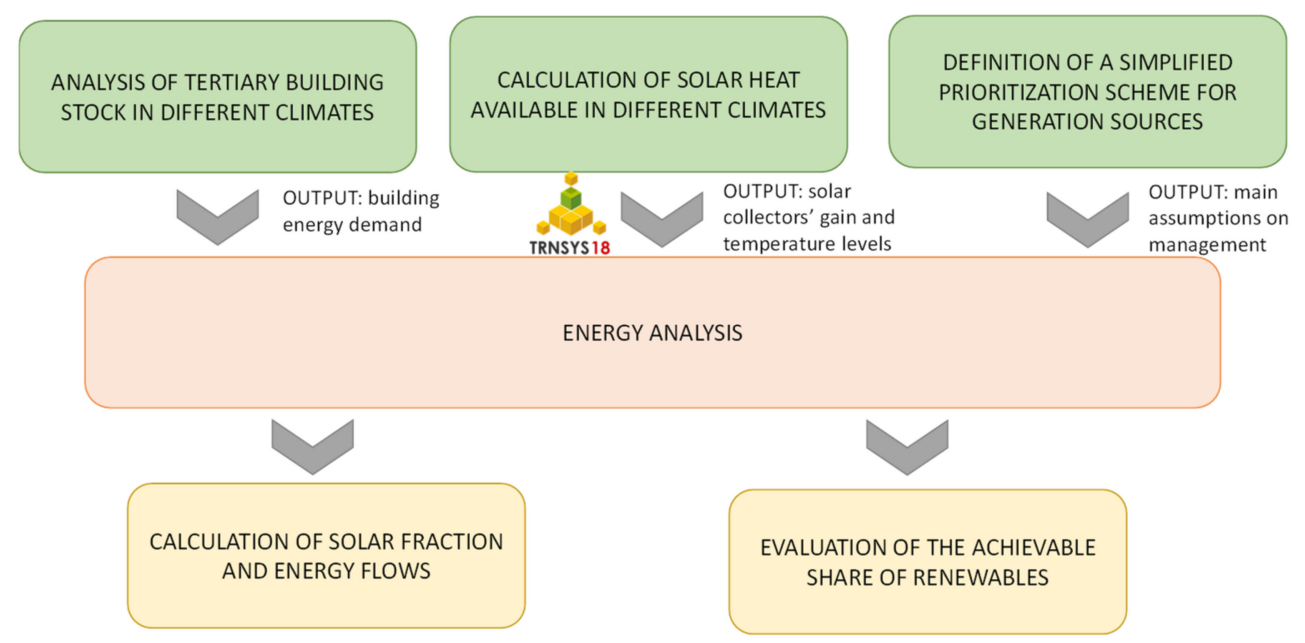

Figure 2. Methodology for the evaluation of the potentiality of the multi-generation system flow chart.

The first step of the analysis was to evaluate the age, distribution and energy demand profiles of offices in different European climates. Characterizing the structure of offices and in general non-residential buildings is complex due to the large varieties of different structures and the poor availability of material in the literature. In the next sections the potential of the multi-generation system is evaluated in non-residential buildings using the office building typology as a reference where construction characteristics and the energy demands were collected from the project ENTRANZE [25] for the cities of Madrid, Berlin and Helsinki. These data were calculated through simulations considering as a reference a five-floor office building with a surface-to-volume S/V ratio of 0.33 and a net heated area of $2400 \mathrm{~m}^{2}$. The DHW demand was obtained from the Standard EN 15316-3-1; the room set-point for winter operation was $21^{\circ} \mathrm{C}(30 \%$ humidity) whereas the room setpoint considered in the summer was $26{ }^{\circ} \mathrm{C}$ and with $70 \%$ of humidity. In both seasons, a ventilation rate of 0.8 air changes/hour was considered.

At the same time, a simplified model was realized in TRNSYS18 [26] for the calculation of the heat available from solar collectors and the correspondent temperature levels for the different locations and times of the year. Further information about the model is reported in Appendix A. The model was structured so that four finite temperature ranges could be obtained as the outlet of solar collectors: $80-90{ }^{\circ} \mathrm{C}, 60{ }^{\circ} \mathrm{C}, 35^{\circ} \mathrm{C}$ and $15{ }^{\circ} \mathrm{C}$. These corresponded to the nominal temperature for the adsorption chiller/ORC operation, DHW provision, space heating and solar-assisted operation of the heat pump, respectively.

Finally, a prioritization scheme was defined to identify which generation source should be preferred for each load. The leading idea behind such a scheme was to prioritize renewable energy over other sources and, among the renewable sources used, to prioritize the solar one over the biomass one. This concept is presented in Figure 3 and can be schematically summarized as follows:

- Heating demand. (1) Solar heat is the preferred source because it is the least dispatchable resource and the one with the lowest environmental impact. In order to activate the direct space heating supply from solar heat, a minimum temperature level of $35^{\circ} \mathrm{C}$ on the solar collectors is needed and up to $80^{\circ} \mathrm{C}$ if there is not a contemporary demand for DHW. (2) The heat pump in the solar source operation is the second choice where solar operation indicates the use of solar heat at $15^{\circ} \mathrm{C}$ as a heat source for evaporation. (3) The biomass boiler, which is basically sized and operated as renewable back-up heating source.

- $\quad$ DHW. (1) Solar heat represents the preferred heat source with (2) the biomass boiler as back-up when solar heat is not available.

- Cooling demand. In colder climates all of the cooling demand is covered with the reversible heat pump. In warmer climates, if there is enough solar heat to drive the 
adsorption module, the operation of the heat pump in cascade operation is preferred in order to minimize the electricity consumption. If there is not enough heat, the reversible heat pump as a stand-alone component is used.

- Electricity generation. In warm climates, (1) TEGs are the preferred system whereas (2) the ORC works only in intermediate seasons because high temperature heat is needed to drive the sorption module during the summer. In cold climates, (1) the ORC is the preferred generation method especially during summer followed by (2) TEGs. There is a third option that is not considered in the present analysis, which is the biomass-driven operation of the ORC. The case studied represents, then, the worst-case scenario (the most conservative one), in terms of the share of renewables because the increased operation of the ORC would reduce the electricity consumption from the grid and therefore from fossil fuels.

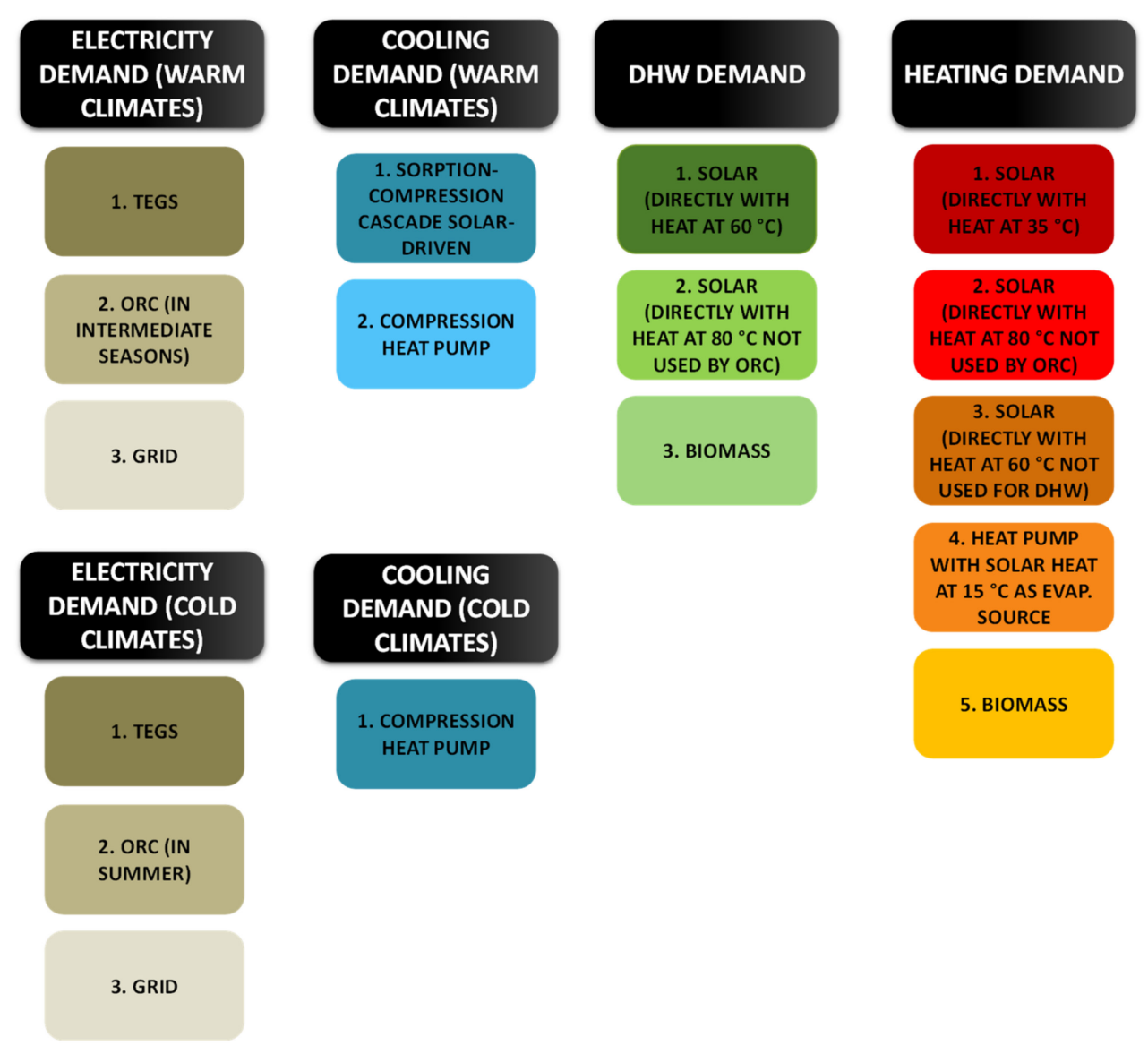

Figure 3. Prioritization of energy sources for each type of load.

\section{Main Assumptions}

Starting from the inputs described above, the systematic assessment of the hybrid system for different scenarios was carried out. For the calculation, several assumptions were made:

1. The flow rate of the thermal fluid of the solar generation section was continuously varied to keep the set outlet temperature.

2. The efficiency of solar collectors was calculated with the TRNSYS model described in Appendix A and was based on the data supplied for commercial components.

3. The combustion efficiency of the biomass boiler was $93 \%$ according to the data provided by the producer (https: / / www.oekofen.com/assets/download/Italienisch_ it/Pelletskessel/Technische\%20Daten/TD_Pellematic_it_aktuell.pdf (accessed on 2 January 2021)). 
4. The EER (energy efficiency ratio) of the heat pump was 3:3 for the solar-assisted operation, 2:5 for the stand-alone operation in the summer and 4:0 for the cascade operation in the summer, corresponding to the performance of a commercial unit taken as reference. The Coefficient of Performance (COP) of the sorption module (thermal efficiency $=$ cooling provided/heat input) was $0.5[22,27]$, the efficiency of the ORC was 4\% [28] and the efficiency of the TEGs was 2.5\% [29]. The efficiency of the cascade adsorption module, ORC and TEGs was considered to be constant.

5. All of the efficiencies of the components were considered constant, regardless of their size and operating conditions (i.e., ambient temperatures and part load). Despite being simplistic assumptions, as cautionary values (a low to medium range of expected ones) were used and given the main aim of the analysis was a reference for the evaluation of renewable penetration in the tertiary sector, they did not represent a limiting factor for the obtained results.

6. The ORC was operated only if solar energy was available whereas the biomass-based operation was not considered. This underestimated the potentiality of the system in terms of overall renewable energy that could be self-consumed but allowed a simplification of the analysis that could be refined once more sophisticated controls were applied.

7. The storages in the system (short-term storage and buffer) were sized in order to compensate for daily fluctuations of the temperatures thus guaranteeing a constant inlet to the user for the hours of the day in which heating, cooling or DHW demand was needed.

8. The electricity produced was used only for the parasitic consumptions of the system (i.e., the pumps and the auxiliaries of the dry cooler) whereas the other internal loads were not part of the analysis.

A summary of the selected cases and main assumptions is given in Table 1.

Table 1. Summary of simulations and main assumptions.

\begin{tabular}{|c|c|c|c|c|c|c|}
\hline City & $\begin{array}{c}\text { Useful Solar } \\
\text { Collectors' Area }\left[\mathrm{m}^{2}\right]\end{array}$ & $\begin{array}{l}\text { Adsorption } \\
\text { Module }\end{array}$ & ORC & Heat Pump: Heating & Heat Pump: Cooling & TEGs \\
\hline Madrid, $50 \%$ & 90 & $\mathrm{COP}=0.5$ & $\eta_{\mathrm{el}}=4 \%$ & $\mathrm{EER}=3.3$ & \multirow{2}{*}{$\begin{array}{c}\text { EER }=4 \text { (cascade } \\
\text { operation), EER }=2.5 \\
\text { stand-alone operation }\end{array}$} & $\eta_{\mathrm{el}}=2.5 \%$ \\
\hline Madrid, $100 \%$ & 180 & $\mathrm{COP}=0.5$ & $\eta_{\mathrm{el}}=4 \%$ & $\mathrm{EER}=3.3$ & & $\eta_{\mathrm{el}}=2.5 \%$ \\
\hline Berlin, $50 \%$ & 90 & not installed & $\eta_{\mathrm{el}}=4 \%$ & $\mathrm{EER}=3.3$ & $\mathrm{EER}=2.5$ & $\eta_{\mathrm{el}}=2.5 \%$ \\
\hline Berlin, $100 \%$ & 180 & not installed & $\eta_{\mathrm{el}}=4 \%$ & $\mathrm{EER}=3.3$ & $\mathrm{EER}=2.5$ & $\eta_{\mathrm{el}}=2.5 \%$ \\
\hline Helsinki, $50 \%$ & 90 & not installed & $\eta_{\mathrm{el}}=4 \%$ & $\mathrm{EER}=3.3$ & $\mathrm{EER}=2.5$ & $\eta_{\mathrm{el}}=2.5 \%$ \\
\hline Helsinki, $100 \%$ & 180 & not installed & $\eta_{\mathrm{el}}=4 \%$ & $\mathrm{EER}=3.3$ & $\mathrm{EER}=2.5$ & $\eta_{\mathrm{el}}=2.5 \%$ \\
\hline
\end{tabular}

\section{Results}

\subsection{Building Characteristics and Energy Demand Profiles}

Generally, an office can be considered to be an entire building, a part of the building or just a room with the main objectives being to provide a comfortable, healthy and safe work environment for the users. Considering the entire building, according to the project iNSPIRE $[30,31]$ most of the office buildings $(85 \%)$ in Spain are built with reinforced concrete and masonry; other structures include glass combined with stainless steel or concrete. Office buildings in Germany generally are built with a reinforced concrete structure including a curtain wall facade. In Finland almost half of non-residential buildings use wood as a construction material. However, the use of concrete and bricks has increased over the years with a reduction of the average global heat transfer, $U$, value $[30,31]$ towards the direction of meeting the requirements established by EU legislation [32]. In this framework, the present study focused on offices whose envelopes were constructed in accordance with the latest national building codes of the corresponding countries [33-35]. The energy demand was calculated through simulations of an office building dimensioned 
according to project ENTRANZE [25]; namely, a five-floor building of south orientation with a total floor area of $2400 \mathrm{~m}^{2}\left(30 \times 16 \times 15 \mathrm{~m}^{3}\right)$ and a total window area of $638 \mathrm{~m}^{2}$. Simulations were performed assuming a thermostat in each conditioned zone set at the setpoint (for the time interval 08:00-18:00) and set-back temperatures (19:00-07:00) shown in Table 2 together with the values of daily DHW consumption and the other parameters used to simulate the overall building performance. Finally, Table 3 reports the U-values of all envelope components as well as the total solar energy transmittance (g-value) of the glasses used during simulations. Weather data were retrieved from the Meteonorm database.

Table 2. Office building simulation parameters (server room values shown in parentheses).

\begin{tabular}{ccc}
\hline \multicolumn{2}{c}{ Parameter } & Value \\
\hline \multirow{2}{*}{ Set-point temperature $\left({ }^{\circ} \mathrm{C}\right)$} & Heating & $20(19)$ \\
\cline { 2 - 3 } & Cooling & $26(26)$ \\
\hline \multirow{2}{*}{ Set-back temperature $\left({ }^{\circ} \mathrm{C}\right)$} & Heating & $15(\mathrm{~N} / \mathrm{A})$ \\
\cline { 2 - 3 } & Cooling & $32(\mathrm{~N} / \mathrm{A})$ \\
\hline \multirow{2}{*}{ DHW consumption $\left(\mathrm{l} / \mathrm{p} /\right.$ day, $\left.60^{\circ} \mathrm{C}\right)$} & 7 \\
\cline { 2 - 3 } Mechanical ventilation & Flow rate $(\mathrm{ACH})$ & 0.84 \\
\hline & Heat recovery ratio & 0.70 \\
\hline
\end{tabular}

Table 3. Average U-values for office buildings in Spain, Germany and Finland [33-35].

\begin{tabular}{ccccccc}
\hline & \multicolumn{7}{c}{ U-Value $\left[\mathrm{W} / \mathbf{m}^{2} \cdot \mathbf{K}\right]$} & \multicolumn{1}{c}{ g-Value (-) } \\
\cline { 2 - 6 } City & Walls & Roof & Basement & Glass & $\begin{array}{c}\text { Internal } \\
\text { Walls/Floors }\end{array}$ \\
\hline Madrid & 0.34 & 0.27 & 0.56 & 2.00 & 1.00 & 0.31 \\
\hline Berlin & 0.24 & 0.20 & 0.30 & 1.30 & 1.00 & 0.63 \\
\hline Helsinki & 0.14 & 0.07 & 0.10 & 0.70 & 1.00 & 0.14 \\
\hline
\end{tabular}

For all countries, the conditioned area of the office building selected was $2400 \mathrm{~m}^{2}$ with a $480 \mathrm{~m}^{2}$ rooftop. Considering the actual space occupied by solar collectors and the minimum distance needed to avoid shading [36], for a 50\% rooftop utilization the useful area of solar collectors was $90 \mathrm{~m}^{2}$ whereas for a $100 \%$ rooftop utilization it was $180 \mathrm{~m}^{2}$.

Figure 4 shows the energy demand (heating, cooling and DHW) estimated for the typology of office building in the three locations selected. In all cases, a cooling demand exists throughout the year. This is due to the server room and its high heat gains. In Madrid (Figure $4 \mathrm{a})$, the highest heating demand happened in December and January $\left(3.7 \mathrm{kWh} / \mathrm{m}^{2}\right)$ and was reduced almost to zero in the spring and summer. The cooling demand showed a peak of $5.7 \mathrm{kWh} / \mathrm{m}^{2}$ in July and August. In Berlin (Figure $4 \mathrm{~b}$ ), the highest heating demand occurred in January with a value of $4.2 \mathrm{kWh} / \mathrm{m}^{2}$. The cooling demand in the summer was relatively high (reaching $7 \mathrm{kWh} / \mathrm{m}^{2}$ in July) especially when compared with Madrid but this was mainly due to the significantly higher g-value of the glasses in Germany. This fact in conjunction with the large window area led to high solar gains and thus to a higher cooling demand. In this context, heating in the summer was not needed. Figure 4c shows the energy demand in office buildings located in Helsinki. In this case, similar conclusions can be drawn. A cooling demand is required throughout the year but to a lesser degree (up to $5.2 \mathrm{kWh} / \mathrm{m}^{2}$ in July) because of the much colder weather. The heating demand reached a maximum in January $\left(4.7 \mathrm{kWh} / \mathrm{m}^{2}\right)$. In all locations, the calculated DHW demand was almost constant throughout the year and corresponded to a value of around $0.5 \mathrm{kWh} / \mathrm{m}^{2}$ per month. 


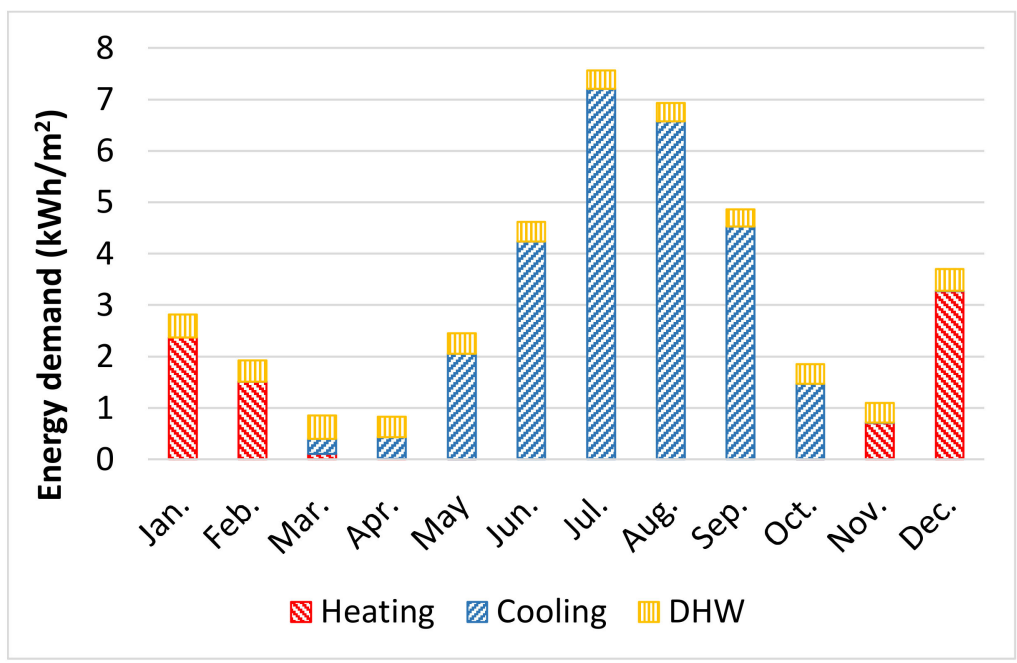

(a)

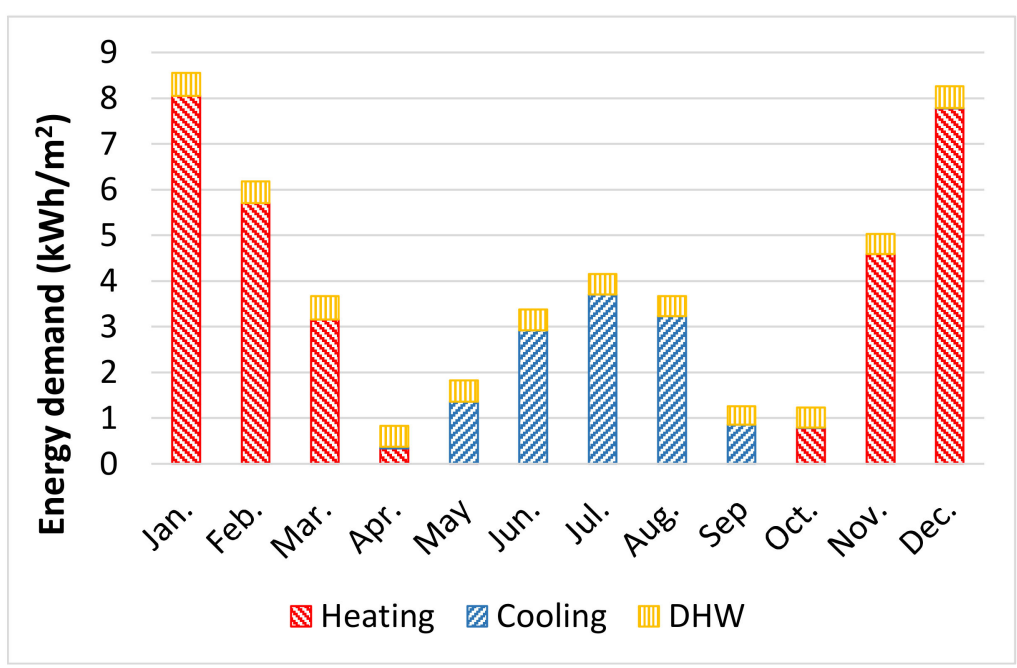

(b)

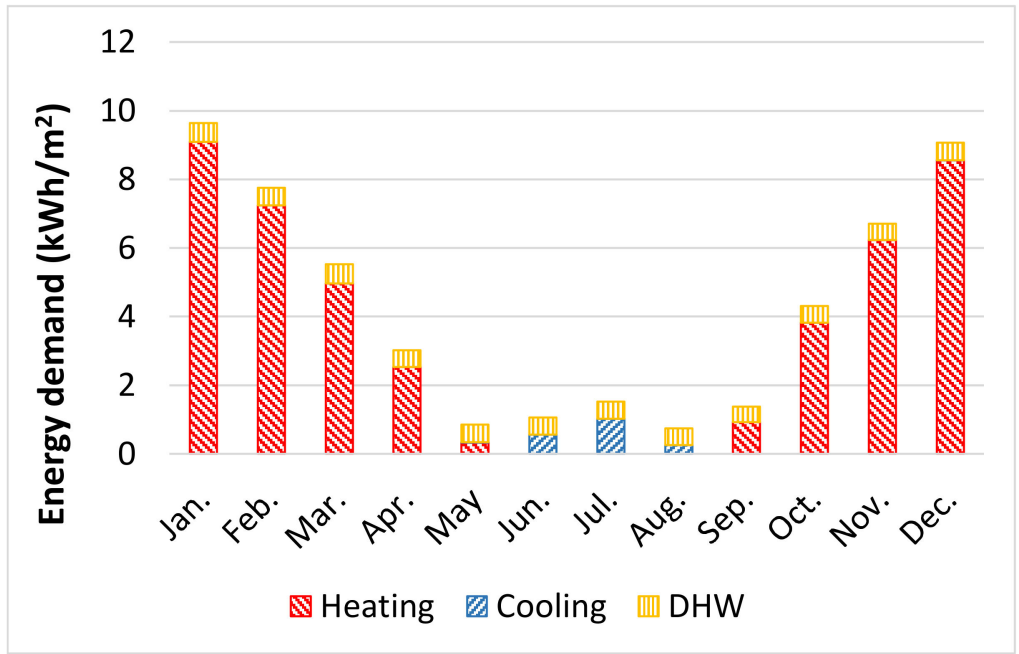

(c)

Figure 4. Monthly energy needs for heating, cooling and domestic hot water (DHW) of office buildings located in Madrid (a), Berlin (b) and Helsinki (c). 


\subsection{Solar Fraction}

As already remarked, the focus of the present analysis was to discuss the achievable target in terms of renewable self-produced energy for offices in different EU climatic conditions. Accordingly, once the main energy contributions were calculated, the solar fraction was evaluated. The solar fractions for heating and DHW were calculated as:

$$
\begin{aligned}
\mathrm{SF}_{\mathrm{DHW}} & =\frac{\mathrm{DHW}_{\mathrm{met}}}{\text { DHW }_{\text {demand }}} . \\
\mathrm{SF}_{\text {heating }} & =\frac{\text { heating }}{\text { met }} \\
\text { heating } & \text { demand }
\end{aligned} .
$$

A solar fraction for cooling was not calculated because in Madrid the system was operated as a cascade chiller meaning that it required a combined operation of the sorption module and the compression unit.

The results are shown in Figure 5. For each climate, two different cases were considered, i.e., with $50 \%$ or $100 \%$ of rooftop covered by solar collectors. Considering $\mathrm{SF}_{\text {heating, }}$ increasing the rooftop covered with solar collectors from $50 \%$ to $100 \%$ led to an increase in the solar fraction from $85 \%$ to $100 \%$ in the climate of Madrid, respectively. This covered the total annual heating demand due to solar energy solely. For both Helsinki and Berlin climates, the higher heating demand and the lower solar irradiation penalized the amount of heat that the solar collectors could directly supply (28\% and $53 \%$ in Berlin for $50 \%$ and $100 \%$ rooftop coverage, respectively, and $27 \%$ and $43 \%$ in Helsinki for $50 \%$ and $100 \%$ rooftop coverage, respectively).

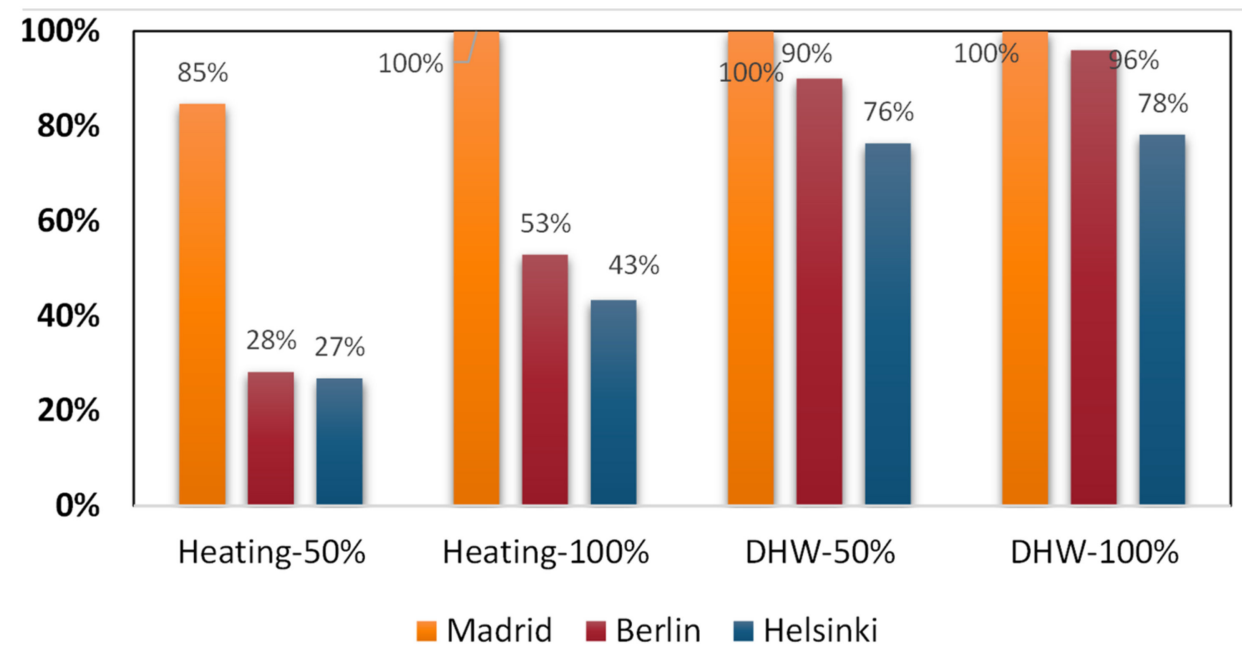

Figure 5. Solar fraction for heating and DHW in the different climates.

Looking at $\mathrm{SF}_{\mathrm{DHW}}$ in Figure 5, values above $75 \%$ could be expected. In Madrid, all of the DHW needed was supplied by solar whereas from $90 \%$ to $96 \%$ could be supplied in Berlin and about $80 \%$ in Helsinki.

\subsection{Energy Flow Analysis}

The energy flows were analyzed and the results are presented in Figures 6-8 for Madrid, Berlin and Helsinki for the case of $100 \%$ rooftop surface with solar collectors. However, the results could also be generalized for the case of $50 \%$ of roof surface with solar collectors. All of the energy flows in the pictures are in $\mathrm{kWh} /\left(\mathrm{m}^{2} \mathrm{y}\right)$. In this section the main results of the energy flow analysis and peculiarities are presented and a critical discussion is included in the next section. As specified in the previous section, the results were based on daily energy balances and are presented as Sankey diagrams to show the overall contribution of each component to the overall energy demand of the building. The 
outcomes of the analysis that can be used for a future optimization of the system were the evaluation of the best configuration for each case (i.e., which components to keep/remove for each climate) and their relative sizing, which would change the relative number of hours of operation. The sizing rules adopted in the energy flow analysis are reported in Appendix B.

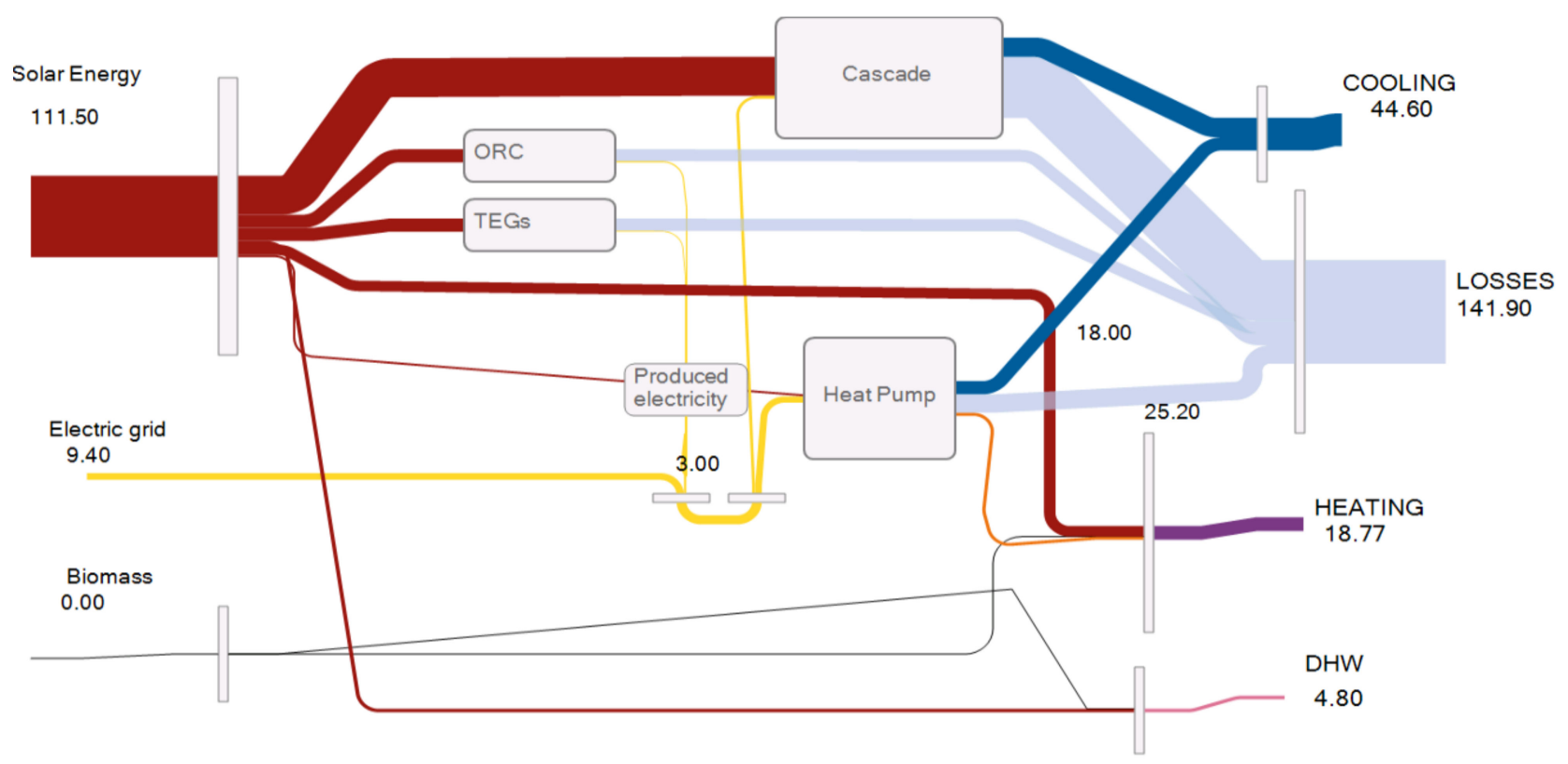

Figure 6. Sankey diagram for Madrid 100\% rooftop coverage with solar collectors. All energy flows are in $\mathrm{kWh} /\left(\mathrm{m}^{2} \mathrm{y}\right)$.

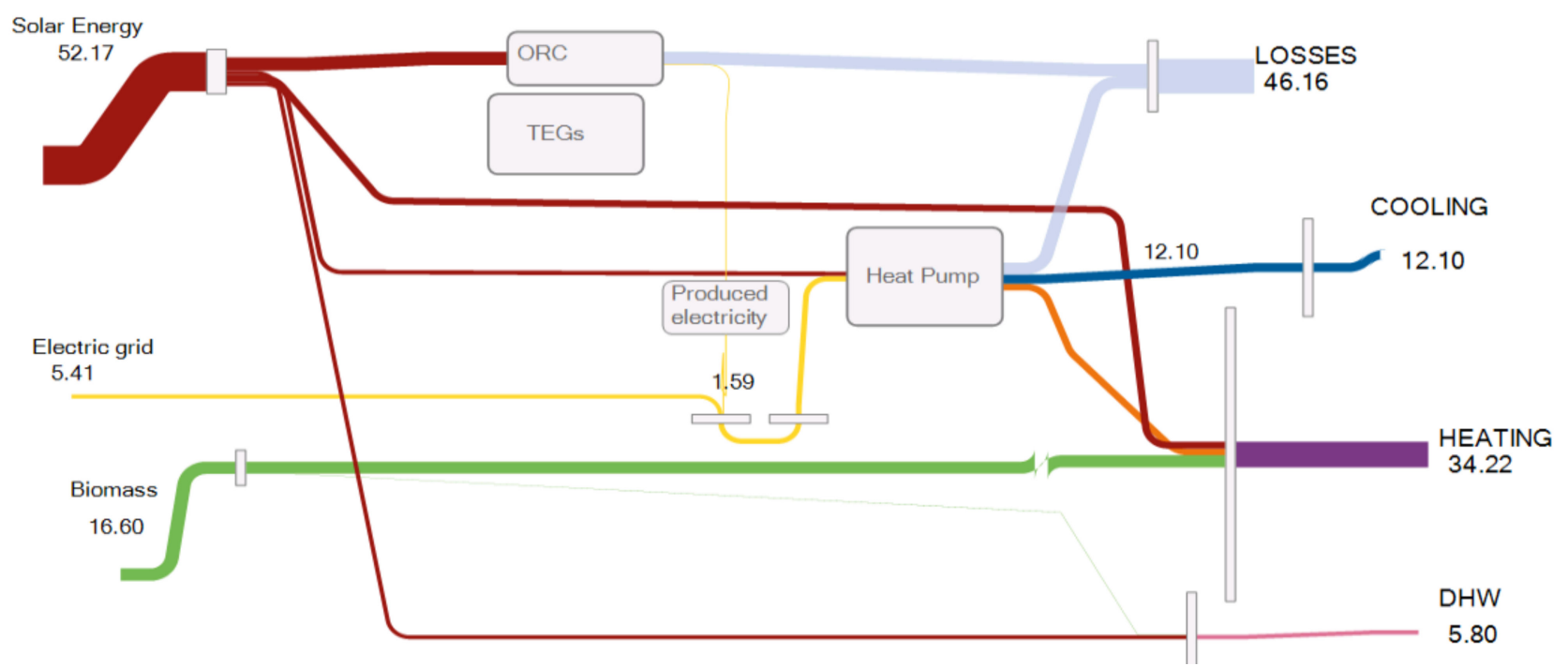

Figure 7. Sankey diagram for Berlin $100 \%$ rooftop coverage with solar collectors. All energy flows are in $\mathrm{kWh} /\left(\mathrm{m}^{2} \mathrm{y}\right)$. 


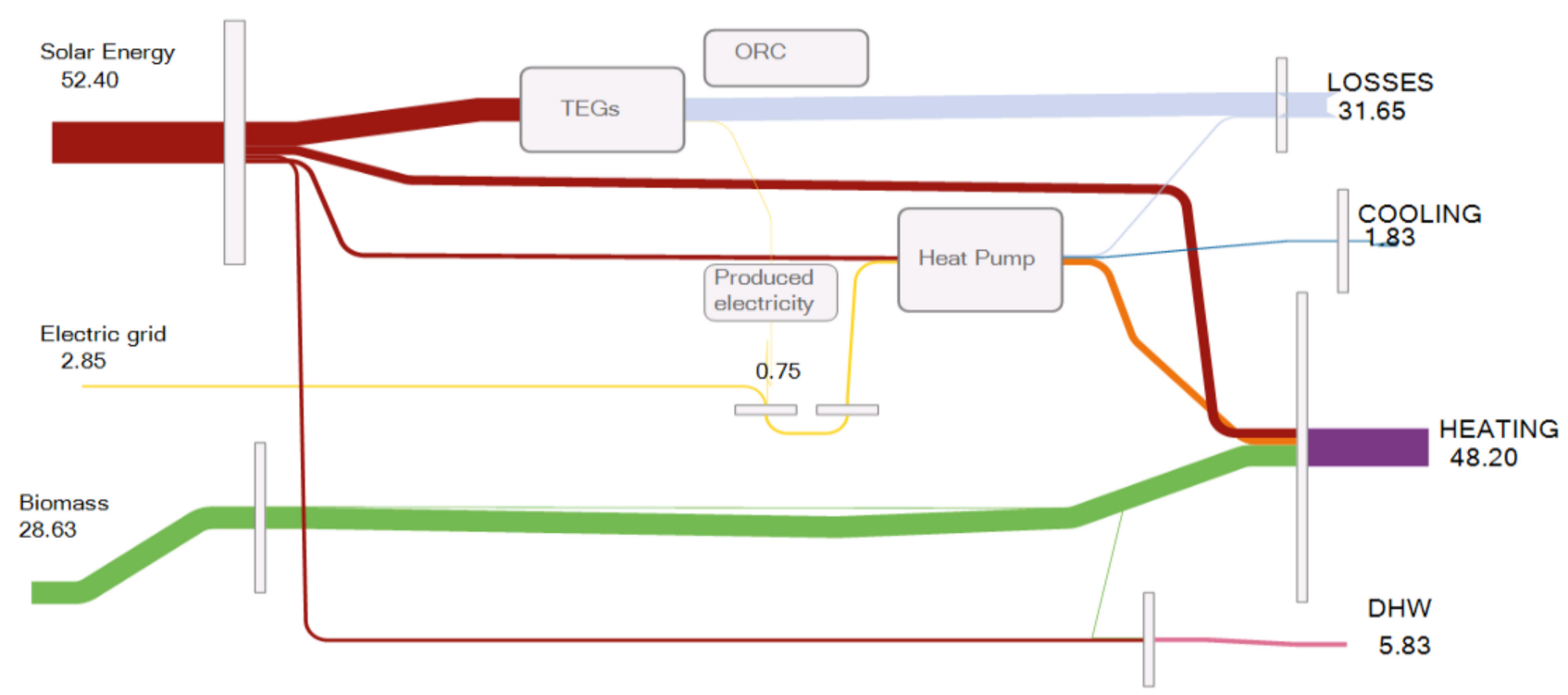

Figure 8. Sankey diagram for Helsinki $100 \%$ rooftop coverage with solar collectors. All energy flows are in $\mathrm{kWh} /\left(\mathrm{m}^{2} \mathrm{y}\right)$.

The results for the case of Madrid are shown in Figure 6. It was noticed that in these conditions, biomass energy was not strictly needed for heating and cooling because the combined operation of direct solar energy at $35^{\circ} \mathrm{C}$ and the use of a heat pump in solarassisted mode could cover all of the theoretical demand. Compared with the results for the other cities, as shown in Figures 7 and 8, the amount of heating that could be supplied by the heat pump in solar-assisted operation (with solar heat as the evaporation source in the winter) was much higher thus actually exploiting to the maximum such a renewable source. The amount of electricity produced with the ORC and TEGs was around $3 \mathrm{kWh} /\left(\mathrm{m}^{2} \mathrm{y}\right)$, therefore covering only about $25 \%$ of the needed amount.

The results for Berlin are shown in Figure 7. It was noticed that the main contribution to space heating came from biomass with an almost equal share of the remaining demand between the heat pump in solar-assisted operation and direct solar energy. Solar energy contributions were almost equally divided for direct space heating and for electricity production through the TEGs whereas a slightly higher share was used for the operation of the ORC. As mentioned, in comparison with Madrid, if the heat pump was operated only when solar heat at $15{ }^{\circ} \mathrm{C}$ was available, the share of heating covered with such a contribution was only about $20 \%$ of the total heating demand. DHW was mainly supplied by solar heat and only a minor integration by the biomass was needed. The share of self-produced electricity was around $1.6 \mathrm{kWhm}^{-2} \mathrm{y}^{-1}$ due to the possibility of operating mainly the ORC for a higher number of hours.

Figure 8 presents the results for Helsinki. Similar to Berlin, the relative contributions of solar energy, the heat pump and biomass were of the same order of magnitude with biomass being the predominant source for heating. Solar energy supplied almost all of the DHW demand and about $25 \%$ of space heating whereas about $20 \%$ could be supplied by the solar-assisted operation of the heat pump. It is worth noticing that this result was strongly influenced by the specific type of building considered, i.e., a tertiary building with a reduced need for DHW and by the comparatively high surface of solar collectors (almost $2000 \mathrm{~m}^{2}$ ). This made it possible, even under low irradiation, to regulate the flow rate of the heat transfer fluid (HTF) in the solar circuit to keep the temperature high enough to produce the DHW needed. For the specific prioritization and management applied, the ORC never operated because due to the higher latitude the outlet temperature from the solar collectors during the intermediate seasons was not enough to drive the ORC. All of the produced electricity, about $0.75 \mathrm{kWh} /\left(\mathrm{m}^{2} \mathrm{y}\right)$, came from TEGs that made use of about $50 \%$ of the overall heat from solar collectors. The cooling demand was negligible because 
only during a few hours (as shown in Figure 4) in August was there the need for such an energy contribution.

\section{Discussion}

\subsection{Layout Adaptation According to Climatic Conditions}

A first evaluation was done on the design and research guidelines towards the application of such a complex and flexible system in office buildings. In order to do so, a techno-economic analysis might be the most appropriate tool but the combination of technologies currently proposed is still far from the market and cost-based information on most components (i.e., the solar collectors with integrated TEGs, the reversible heat pump) cannot be estimated with sufficient confidence. Accordingly, economic considerations have not been used as criteria for the evaluation of the system. Nonetheless, it is worth remarking that the results presented here indicated the promising potential of the system, which could boost research and increase the maturity of the system towards a practical application.

Figures 9 and 10 show the contributions of the different heating sources for space heating and DHW purposes. All of the examined cases (i.e., locations and extension of solar collectors) were reported to better compare the different cases. It was noticed that, passing from the southern location (Madrid) to the northern one (Helsinki), the contribution of the heat pump to the overall space heating supply changed. Indeed, for the selected control strategy, the heat pump was operated only at high efficiency when heat at low temperatures $\left(15-20{ }^{\circ} \mathrm{C}\right)$ from solar collectors could be exploited. As in northern countries the available heat in the winter is usually low, using the heat pump for space heating is not convenient. Therefore, while in Madrid the share of heating produced by the heat pump was 20-35\% (according to the number of solar collectors installed), it was only around 10\% in Berlin and almost zero in Helsinki. However, it is worth remarking that the specific energy mix for electricity in Helsinki and Berlin included a larger share of renewables [37-39] than in Madrid. This meant that an optimization of the system with the scope of maximizing the use of renewables (both direct for self-production and indirect from a country-specific energy mix) might be to increase the operating hours of the heat pump during winter. As discussed in the previous section, the contribution of biomass was needed only for $50 \%$ of roof surface coverage with solar collectors in Madrid. In Berlin and Helsinki, biomass was needed to cover from $40 \%$ to $50 \%$ of the share for space heating. In this case, the system for very cold climates could be simplified, avoiding the installation of the heat pump and relying only on solar collectors and biomass for space heating purposes. However, this conclusion should be supported with a cost-benefit analysis that is not included in this study.

The DHW demand could be efficiently and to a large extent covered by using solar energy in all climates including Helsinki. It is worth stating, however, that such a result is extremely dependent on the building type considered; office buildings are characterized by a low DHW request. Considering instead the DHW demand for residential purposes or for other tertiary buildings such as hotels, it might be significantly higher therefore reducing the flexibility of the operation of the proposed hybrid system.

To deeper understand the possibility of the system in terms of renewable energy utilization, the electricity produced and supplied by the grid is shown in Figure 11 for all of the six scenarios investigated. It is necessary to remark that both the operating hours of the TEGs and the ORC might be underestimated; as explained in Section 4, the ORC in the present analysis was run only when there was solar heat available whereas in the real system implementation it would be possible to also use the biomass boiler when there was not any contemporary need for space heating or DHW. Similarly, the TEGs were operated only with solar heat at $50-60{ }^{\circ} \mathrm{C}$ but they could also be operated in "night mode", i.e., exploiting heat rejected at low temperatures and heat from the short-term storage (at $\mathrm{T}<60^{\circ} \mathrm{C}$ ) during the night for electricity production [40]. Both in Berlin and Helsinki for the smaller collectors' surface, the TEGs were not operated. This was due 
to the fact that the heat at the temperature level needed for TEGs operation was mainly used for DHW according to the prioritization scheme in Figure 3. The contribution of the ORC instead was $9 \%$ in Berlin and $11 \%$ in Helsinki for $50 \%$ solar collectors, showing a good potential for the application of such a system. For the larger collectors' surface, in Helsinki only the TEGs were operated. This was due to the lack of a significant amount of heat at $90{ }^{\circ} \mathrm{C}$ even in the summer needed to drive the ORC whereas more operating hours were guaranteed by TEGs. In this climate, the use of a biomass-driven operation of the ORC could represent the best solution to reduce the electricity drained from the grid. Berlin represented the most balanced case (with the larger extension of solar collectors) because up to $30 \%$ of renewable electricity out of the total needed for the auxiliaries could be produced equally distributed between TEGs $(14 \%)$ and the ORC $(15 \%)$ even under the oversimplified management applied. In Madrid, a large share of heat at high temperature was needed to drive the cascade chiller. Therefore, for the $50 \%$ coverage scenario, only the TEGs were operated whereas a balance between the ORC and TEGs existed for the $100 \%$ case and up to $35 \%$ of overall electricity used came from self-production.

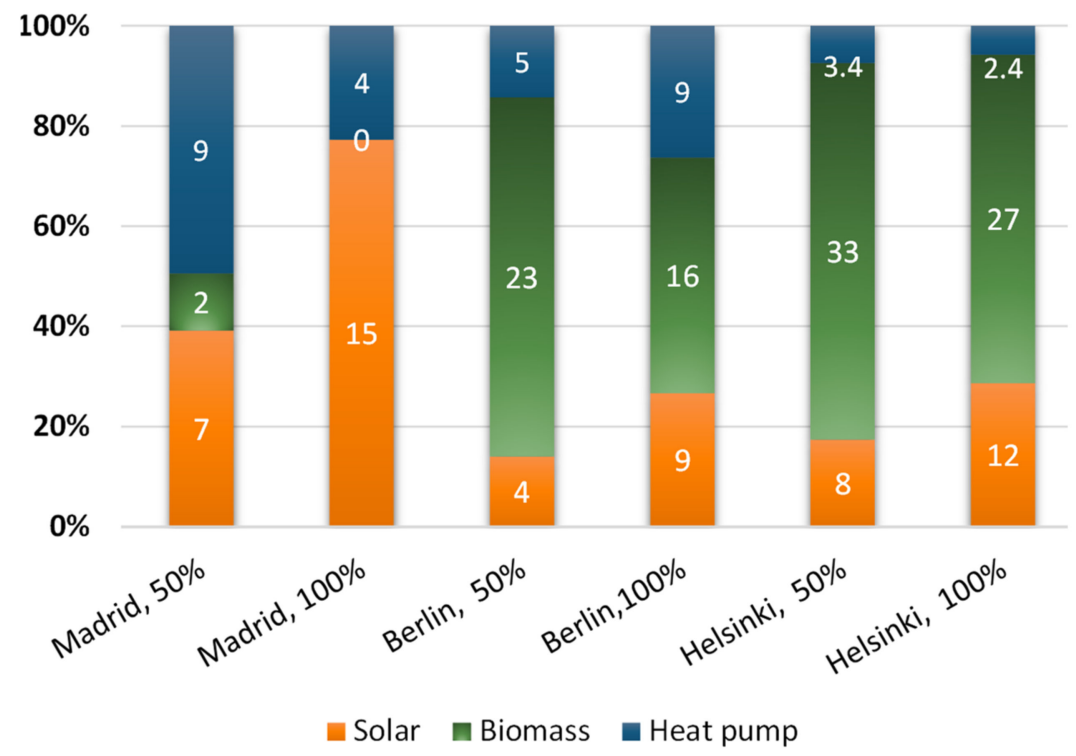

Figure 9. Relative share of space heating energy sources. The numbers in white indicate the $\mathrm{kWh} /\left(\mathrm{m}^{2} \mathrm{y}\right)$.

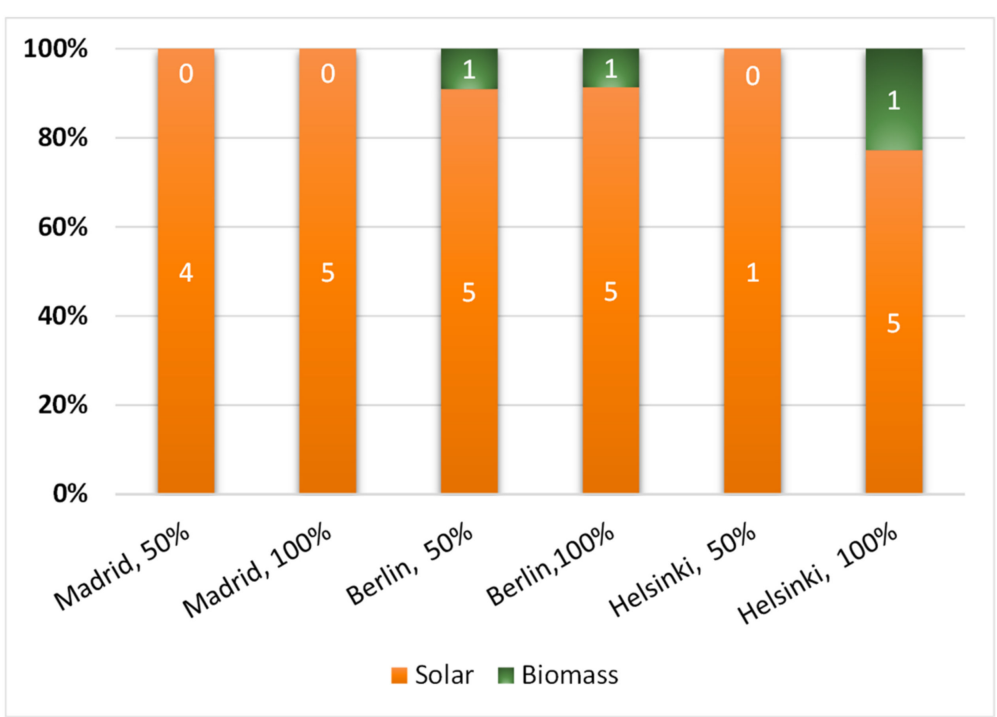

Figure 10. Relative share of heating sources for DHW. The numbers in white indicate the $\mathrm{kWh} /\left(\mathrm{m}^{2} \mathrm{y}\right)$. 


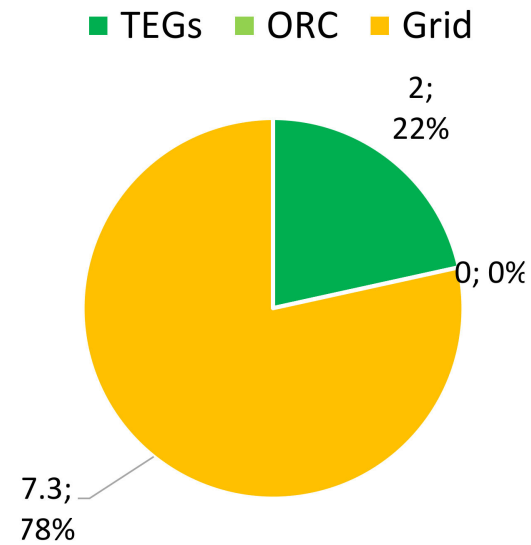

(a)

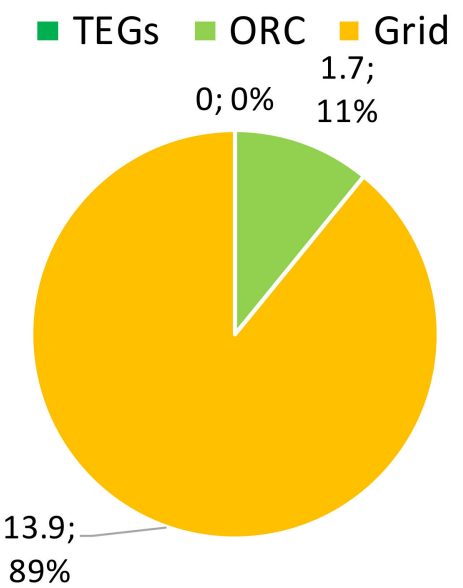

(c)

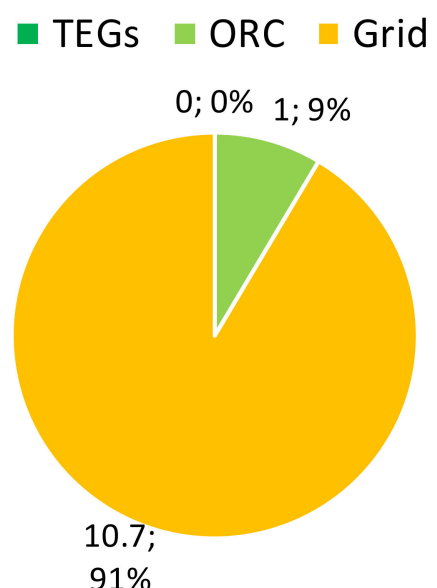

(e)

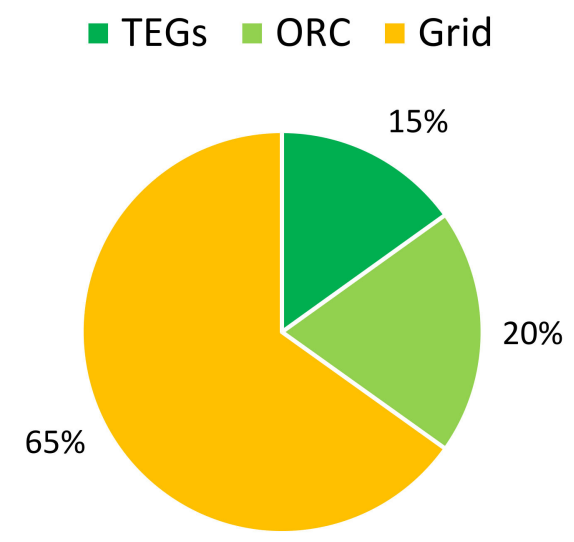

(b)

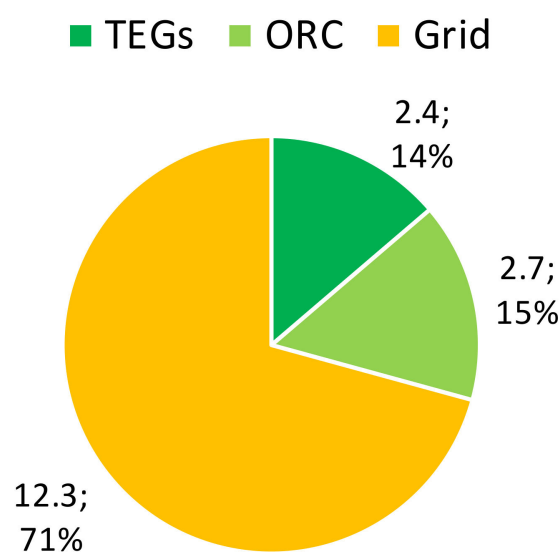

(d)

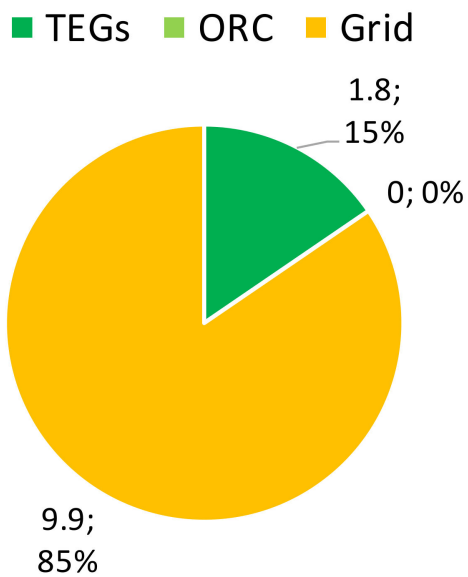

(f)

Figure 11. Electricity generation sources in Madrid for 50\% rooftop coverage with solar collectors (a) and $100 \%$ (b); in Berlin for $50 \%$ rooftop coverage with solar collectors (c) and $100 \%$ (d) and in Helsinki for $50 \%$ rooftop coverage with solar collectors (e) and $100 \%$ (f). The numbers in the plots indicate the $\mathrm{kWh} /\left(\mathrm{m}^{2} \mathrm{y}\right)$ for each contribution and the relative share of the overall electricity consumption for the heat pump and auxiliaries.

Such results prove the great flexibility of the proposed hybrid system, which can be easily adapted to all of the different scenarios and, if properly managed, can efficiently exploit different generation sources for a non-residential user allowing long operating 
hours on renewables only. The results will also be used as a starting basis for the definition of an advanced control system. In order to properly manage the multi-generation system proposed, artificial intelligence-based techniques can be used that define the scheduling and operating hours of components based on weather forecasts, predicted energy demand and energy prices using self-consumption as the objective function.

\subsection{Comparison with Residential Buildings}

The methodology and energy analysis that were presented in the previous sections were also applied by the authors for evaluating the alternatives and possible share of renewables in residential buildings [21]. The main peculiarity of office buildings over residential ones is the lower DHW demand compared with the heating/cooling one. In the case of residential buildings, two different scenarios were considered; i.e., standard buildings (representative of the current building stock distribution) and new and renovated buildings considering the nZEB directives in force for the residential stock at a European level.

One significant difference in the operation of the system for the two cases is that for office buildings the $\mathrm{SF}_{\text {heating }}$ is higher than in residential ones but the $\mathrm{SF}_{\mathrm{DHW}}$ is lower because a higher share of solar heat is needed to cover the space heating. Moreover, at a building level, the integration from the heat pump is mainly used for cooling whereas in offices it is used to some extent ( $20 \%$ to $35 \%$ of overall annual demand) for heating.

This indicates that in office buildings different layouts and operational strategies should be considered. For instance, if the focus of the installation is to cover heating and DHW demand with the highest solar fraction possible, components such as TEGs are not needed in the installation, which can then be simplified. On the contrary, due to the need for biomass integration, it is also possible to design the system in order to increase the self-production of electricity through the ORC (mainly in Madrid and Berlin) or TEGs (mainly in Madrid and Helsinki).

If a comparison is made on the total share of renewables achieved in both cases, the results for offices and buildings are comparable as the lower demand covered by renewables in offices for electricity and DHW is compensated by the higher solar share for heating, further demonstrating that the flexibility of the proposed system goes in the direction of an increased self-consumption and decentralized energy generation.

\subsection{Towards a $100 \%$ Renewable Scenario}

The ultimate goal of the study here presented is the answer to the following question: can we use a multi-generation system such as the one presented to consume $100 \%$ renewable energy? In order to answer such a question, the amount of renewable energy over the total energy demand (share of renewables) to supply heating, cooling, DHW and electricity (for the heat pump and auxiliaries only) is shown in Figure 12 for the different solar collectors' rooftop covering. For a fair comparison, the contribution of the electricity taken from the grid for the heat pump and auxiliaries was weighted considering the following share of renewable generation for the national electrical grid: 47\% in Germany [41], 46\% in Finland [42] and 33\% in Spain [43]. What is clear is that even with the simplifications applied, a share of renewables of $100 \%$ for DHW is possible in all locations and more than $80 \%$ of the heating request is covered only using renewable energy with a share up to 92\% in Berlin and Helsinki. In Madrid, especially for the larger collectors' installation, even cooling is almost totally covered by using solar heat. The relatively low share of renewables for cooling in Helsinki and Berlin should not be misinterpreted; as shown in Section 5.1, the cooling demand in Helsinki is practically zero and therefore having more than $90 \%$ of renewables for heating and DHW already indicates that the path towards a fully sustainable building is reached. Similarly, the cooling demand in Berlin is only $7 \%$ of the overall heating demand and therefore the share of the non-renewables on the absolute amount is low as well. As shown also is that the share of electricity, which is another $5 \%$ of the overall energy demand in Berlin and Helsinki, can be more efficiently produced. 


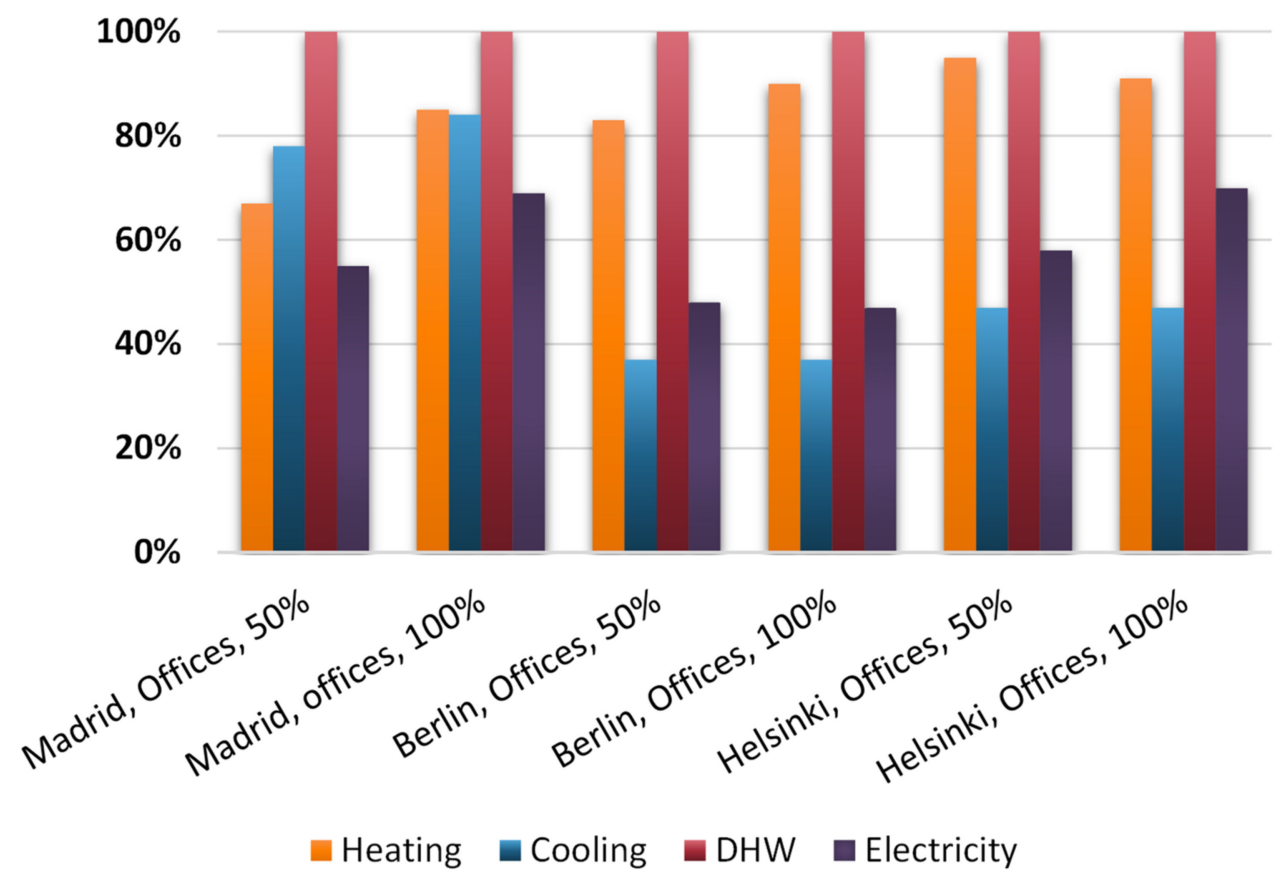

Figure 12. Share of renewables for the examined cases.

It is then possible to state that the road for reaching a full operation with renewables with the proposed solution is close, thus entirely proving that the use of multiple generation sources and a creative and flexible configuration with adaptable components and management is the key for the sustainable cities of the future.

In this regard, it is worth noticing that the solar-biomass-sourced system introduces a great complexity compared with standard systems and there is a need for several additional components. To cover for this extra complexity, a strong action at a regulatory/policy framework level is needed through financial aids (i.e., incentives for equipment purchasing) and energy efficiency and distributed renewable generation at a building level. This is indeed the path indicated by the EU in the Clean Energy for all Europeans package [44] where a set of energy efficiency/renewable generation targets is indicated and the commitment towards financial instruments to achieve the green transition are reported. This would greatly facilitate the market penetration and the economic sustainability of the solution proposed here. At the same time, strong research is needed at a control level; the great level of complexity calls for a control strategy that combines multiple objectives and the need to include model predictive features [45-47] in order to achieve an optimized operation and, at the same time, relieve the burden on the electric grid and increase revenues for the building owner.

\section{Conclusions}

The present paper discusses the application of a solar-biomass system for heating, cooling, DHW and electricity production applied to office buildings. The system mainly consists of solar collectors with TEGs, a biomass boiler and a reversible heat pump/ORC that, in summer mode, can be operated as a cascade system by coupling it to an adsorption module.

A literature survey on the energy demand of the building stocks and a simplified TRNSYS model to define available solar heat at various temperature levels were used as the input for an energy analysis. The results were reported showing the energy flows between the various components of the system. Six scenarios were considered; an installation in Madrid, Helsinki and Berlin with solar collector surfaces of $50 \%$ and $100 \%$ of the total rooftop area. The focus of the analysis was the identification of the potentiality of the system in terms of share of renewables achievable and showed that, in all locations, $100 \%$ 
of DHW was obtained with renewable energy, mainly exploiting solar heat. In Madrid, where the cascade chiller operated in the summer, up to $90 \%$ of the cooling demand could be covered using the solar-driven adsorption-compression system. The share of renewables for heating varied between $70 \%$ in the case of Madrid (where solar heat represented the predominant contribution also in the winter) and up to $92 \%$ for Berlin and Helsinki (where the majority of the heating request is supplied by the biomass boiler). Future activities will be devoted to the further development of components and to the definition of advanced control logics with the aim of increasing even more the amount of renewable energy exploited towards a $100 \%$ scenario.

Author Contributions: Conceptualization, S.K., L.F.C., A.F.; methodology, E.B., A.C., V.P.; formal analysis and validation, E.B., A.C., V.P.; visualization, V.P., E.B.; writing-original draft preparation, V.P., E.B.; writing-review and editing, A.C., S.K., L.F.C., A.F. All authors have read and agreed to the published version of the manuscript.

Funding: This project has received funding from the European Union's Horizon 2020 research and innovation program under grant agreement No 814945 (SolBio-Rev).

Institutional Review Board Statement: Not applicable.

Informed Consent Statement: Not applicable.

Data Availability Statement: Data is contained within the article.

Acknowledgments: The authors at the University of Lleida would like to thank the Catalan Government for the quality accreditation given to their research group (2017 SGR 1537). GREiA is a certified agent TECNIO in the category of technology developers from the Government of Catalonia. This work is partially supported by ICREA under the ICREA Academia program.

Conflicts of Interest: The authors declare no conflict of interest.

$\begin{array}{ll}\text { Abbreviations } & \\ \mathrm{A} & \text { Area, } \mathrm{m}^{2} \\ \mathrm{a}_{0} & \text { Zero-order coefficient solar collector efficiency } \\ \mathrm{a}_{1} & \text { First-order coefficient solar collector efficiency, } \mathrm{W} /\left(\mathrm{m}^{2} \mathrm{k}\right) \\ \mathrm{a}_{2} & \text { Second-order coefficient solar collector efficiency, } \mathrm{W} /\left(\mathrm{m}^{2} \mathrm{k}^{2}\right) \\ \mathrm{G} & \text { Solar radiation, } \mathrm{W} / \mathrm{m}^{2} \\ \mathrm{~K}_{\Phi \mathrm{l}} & \text { Angle modifier in longitudinal direction } \\ \mathrm{K}_{\Phi \mathrm{t}} & \text { Angle modifier in transversal direction } \\ \mathrm{Q} & \text { Energy, } \mathrm{kJ} \\ \mathrm{Q} & \text { Thermal Power, } \mathrm{kW} \\ \mathrm{T} & \text { Temperature, } \\ \mathrm{U} & \text { Heat transfer coefficient, } \mathrm{W} /\left(\mathrm{m}^{2} \mathrm{~K}\right) \\ \mathrm{Subscripts} & \\ \mathrm{amb} & \text { Ambient } \\ \mathrm{m} & \text { Medium } \\ \text { out } & \text { Outlet } \\ \mathrm{Abbreviations} & \\ \mathrm{COP} & \text { Coefficient of Performance } \\ \mathrm{DHW} & \text { Domestic hot water } \\ \mathrm{EER} & \text { Energy efficiency ratio } \\ \mathrm{IAM} & \text { Incident angle modifier } \\ \mathrm{HTF} & \text { Heat transfer fluid } \\ \mathrm{HP} & \text { Heat pump } \\ \mathrm{ORC} & \text { Organic Rankine Cycle } \\ \mathrm{SF} & \text { Solar fraction } \\ \mathrm{TEG} & \text { Thermoelectric generator } \\ & \end{array}$




\section{Appendix A. Calculation of Solar Heat Available}

The solar heat available and the temperature levels of the solar collectors in different conditions were calculated using a dynamic model implemented in TRNSYS18, shown in Figure A1. It consists of:

- Solar collectors (type 539). Among the different control strategies that could be chosen for this type, the one with fixed outlet temperature $\mathrm{T}_{\text {out }}$ was selected;

- A thermal dissipator with a fixed $\Delta \mathrm{T}$ between the inlet and the outlet of the HTF circuit $\left(\Delta \mathrm{T}_{\text {set }}=10 \mathrm{~K}\right)$;

- A variable speed pump was used. The control signal for the speed of the pump was directly supplied by type 539 (the type used to simulate the solar collector), that included different possible management strategies.

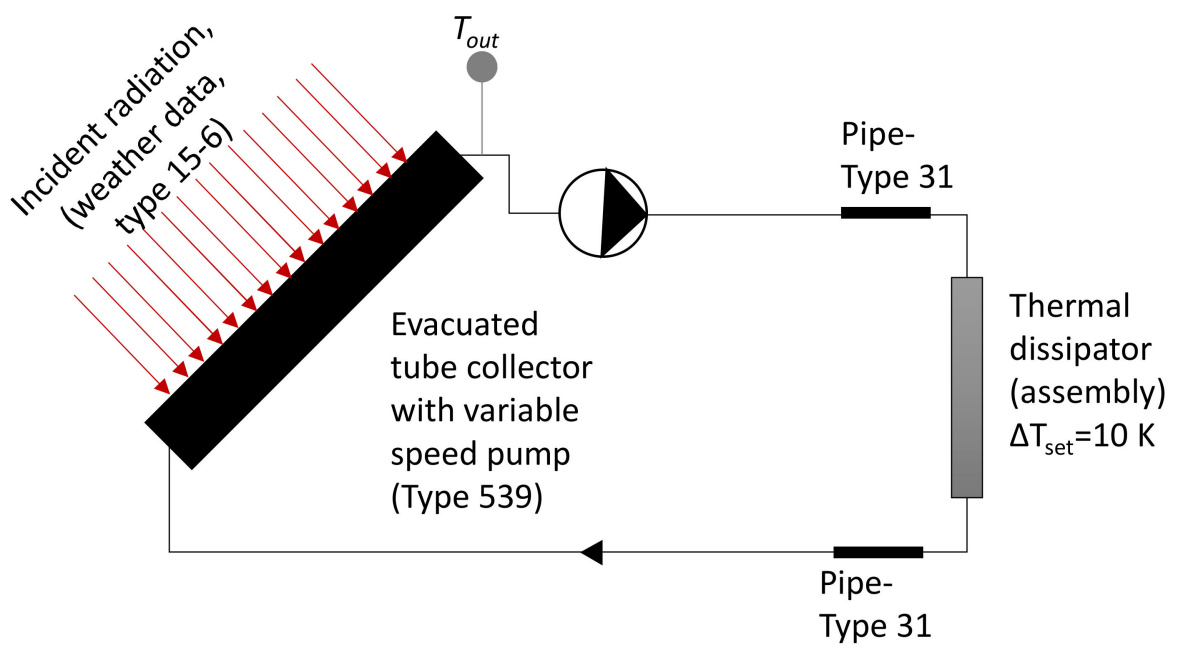

Figure A1. Schematic layout of TRNSYS model realized for heat available calculation.

The solar collectors modelled were based on AKOTEC OEM Vario 2400-30 hp that are the basis for the optimized solar collectors developed in the SolBio-Rev project. The efficiency of the solar collectors can be expressed as [48]:

$$
\frac{\dot{\mathrm{Q}}}{\mathrm{A}}=\mathrm{G}\left(\mathrm{a}_{0}-\mathrm{a}_{1} \frac{\left(\mathrm{T}_{\mathrm{m}}-\mathrm{T}_{\mathrm{amb}}\right)}{\mathrm{G}}-\mathrm{a}_{2} \frac{\left(\mathrm{T}_{\mathrm{m}}-\mathrm{T}_{\mathrm{amb}}\right)^{2}}{\mathrm{G}}\right)
$$

where $\dot{Q}(\mathrm{~kW})$ is the solar gain of the collectors, $A\left(\mathrm{~m}^{2}\right)$ is the surface of the collectors, $\mathrm{T}_{\mathrm{m}}$ $\left({ }^{\circ} \mathrm{C}\right)$ is the average temperature of the solar collectors, $\mathrm{T}_{\mathrm{a}}\left({ }^{\circ} \mathrm{C}\right)$ is ambient temperature and $\mathrm{G}\left(\mathrm{kW} / \mathrm{m}^{2}\right)$ is the incident radiation on the solar collectors. The coefficients $\mathrm{a}_{0}, \mathrm{a}_{1}$ and $\mathrm{a}_{2}$ that define the performance of the collectors were obtained through standardized tests. The collectors chosen are reported in Table A1.

Table A1. Coefficients of the solar gain equation for the AKOTEC collectors.

\begin{tabular}{cl}
\hline Coefficient & Value \\
\hline $\mathrm{a}_{0}$ & 0.703 \\
\hline $\mathrm{a}_{1}\left[\mathrm{~W} /\left(\mathrm{m}^{2} \mathrm{~K}\right)\right]$ & 2.224 \\
\hline $\mathrm{a}_{2}\left[\mathrm{~W} /\left(\mathrm{m}^{2} \mathrm{~K}^{2}\right)\right]$ & 0.005 \\
\hline
\end{tabular}

In addition, incident angle modifiers (IAMs) were used, which are shown in Figure A2. IAMs represent the variation of the solar gain of the collectors according to the changes of the angle of the sun in relation to the surface of the collector. For anisotropic collectors such as the ones considered in this analysis, two separate incidence angle modifiers, the 
longitudinal $\mathrm{K} \theta \mathrm{L}$ and the transversal $\mathrm{K} \theta \mathrm{T}$, need to be defined (see Figure A2) [48]. As shown, the efficiency of the collectors remained high until a $60^{\circ}$ incident angle was reached.

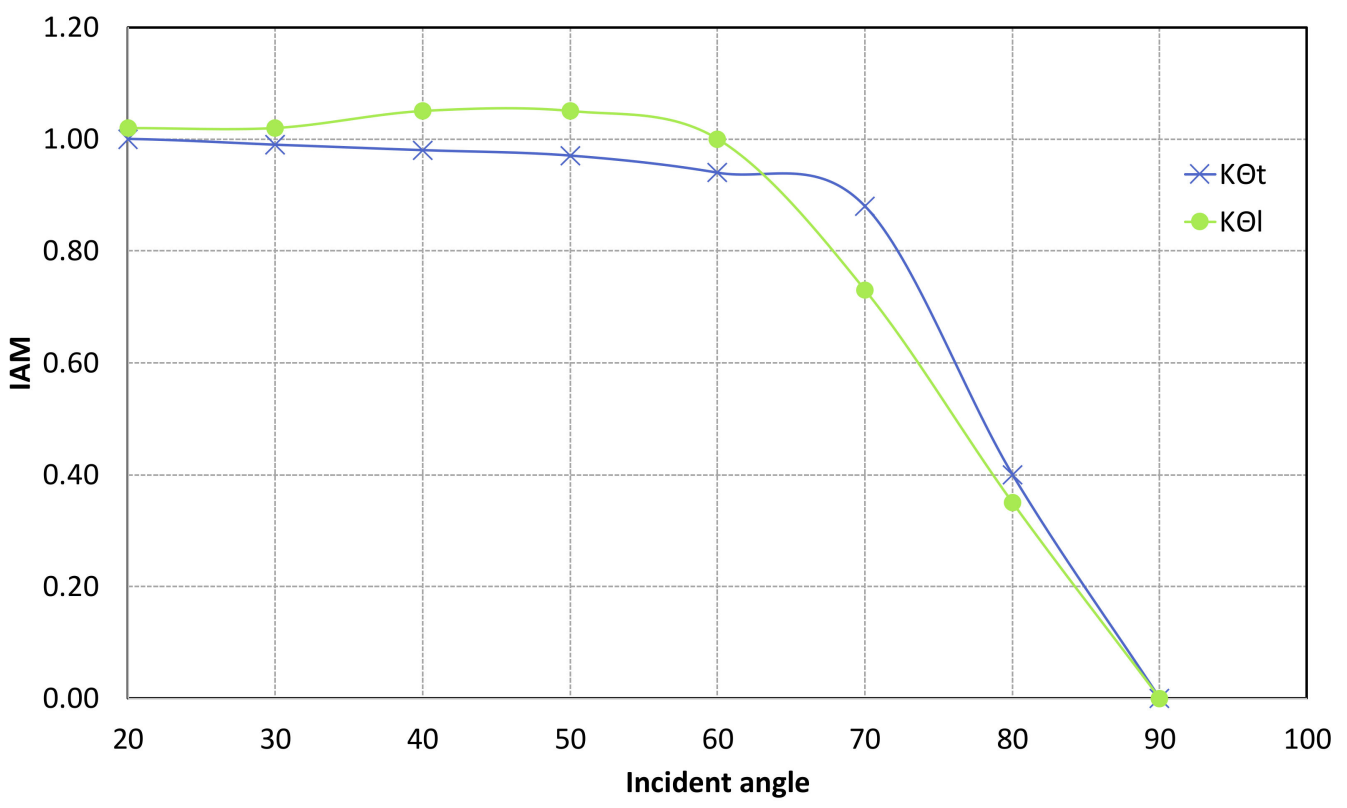

Figure A2. Incident angle modifiers (IAMs) for the collectors chosen.

For the locations considered, the optimal slopes for the installation of the solar collectors are reported in Table A2 [49].

Table A2. Slopes for the installation of the solar collectors in the cities considered.

\begin{tabular}{cc}
\hline City & Slope \\
\hline Madrid & $25^{\circ}$ \\
\hline Berlin & $35^{\circ}$ \\
\hline Helsinki & $45^{\circ}$ \\
\hline
\end{tabular}

The heat losses of the piping were considered by using DN32 piping (as recommended by the producer of solar collectors) including a typical solar tubing insulation and an overall length of the circuit of $10 \mathrm{~m}$ for each $10 \mathrm{~m}^{2}$ of solar collectors. The convective heat loss coefficient to the ambient was estimated as $\mathrm{h}_{\text {loss }}=0.7512 \mathrm{~W} /\left(\mathrm{m}^{2} \mathrm{~K}\right)[50]$.

The desired outlet temperature $T_{\text {out }}$, which set the temperature level for the solar heat at each time step of the solver, was variable according to solar incident radiation, ambient temperature and DHW demand. In particular, it was set in order to allow, during winter, the possibility of providing space heating, DHW and an evaporation heat source to the heat pump. During summer, the main goal was to have high temperature heat for driving the adsorption module (in warmer climates) or the ORC (in colder climates). It is important to remark that the proposed management strategy was based on simplified evaluations and that further refinement, i.e., based on weather forecasts and more complex algorithms, could further increase the heat gain from the solar collectors. The control rules chosen are summarized in Figure A3. 


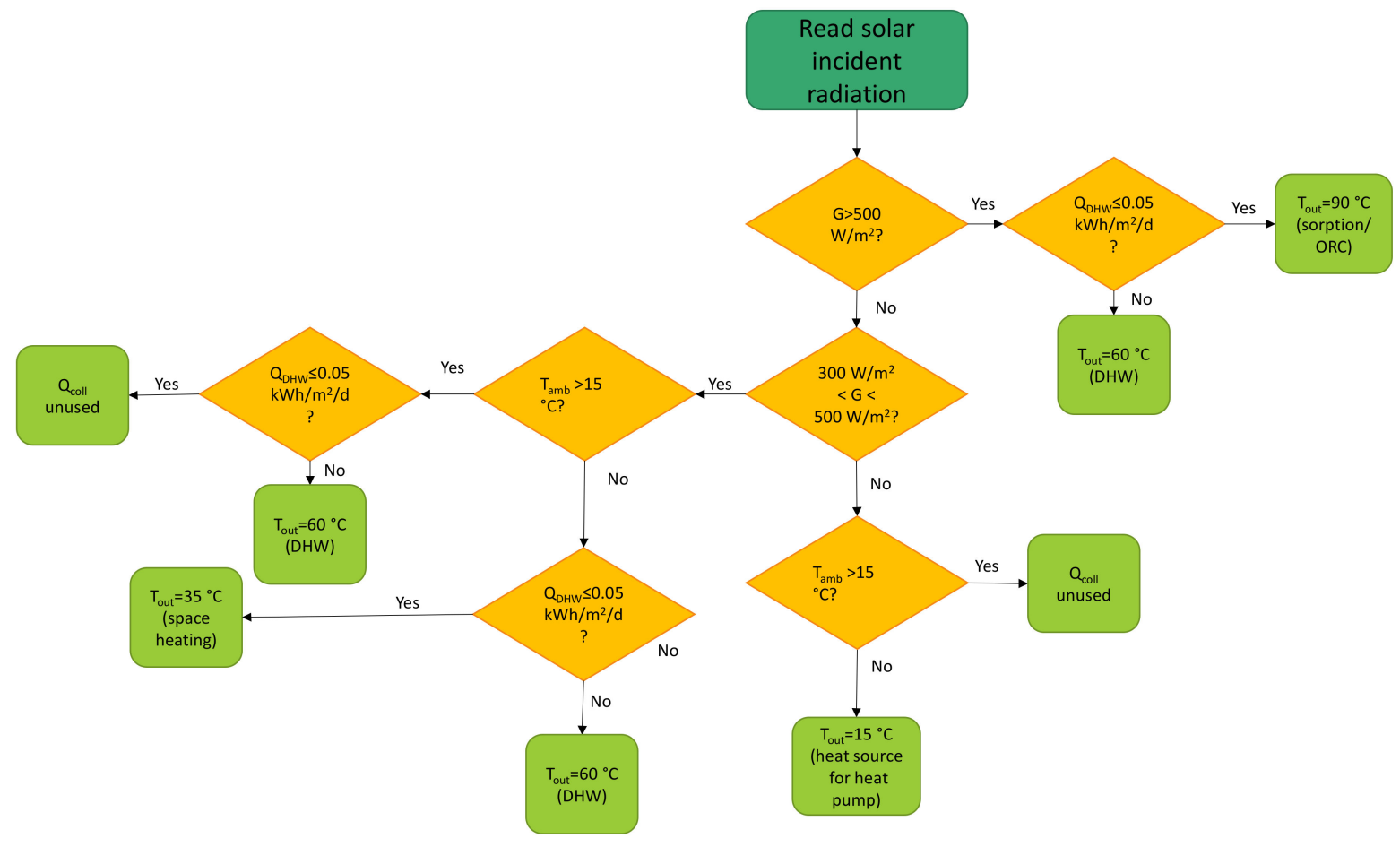

Figure A3. Control of the outlet temperature from the solar collectors.

\section{Appendix B. Sizing Considerations}

The system proposed was a configuration based on preliminary evaluations of the performance of components whose relative sizing would be refined using dedicated algorithms. However, in order to better understand the methodology followed, the main sizing considerations analysis are here reported. The starting point for sizing was the evaluation of the available surface for solar collectors, which was varied according to the climate. The reversible heat pump/ORC for each climate was sized considering the possibility of covering at least $80 \%$ of peak demand. One of the main distinguishing features of the hybrid solution presented was the integration of the heat pump cycle directly into the sorption cycle thanks to a single component that worked as condenser of the heat pump and evaporator of the sorption cycle. It follows that the minimum size for the sorption chiller was strictly dependent on the size of the reversible heat pump [23]:

$$
\dot{\mathrm{Q}}_{\text {cool,sorption }}=\dot{\mathrm{Q}}_{\text {cond, } \mathrm{VCC}}
$$

where $\dot{Q}_{\text {cool,sorption }}$ is the cooling power of the sorption chiller under nominal design conditions and $\dot{\mathrm{Q}}_{\mathrm{cond}, \mathrm{VCC}}$ is the condensation power of the heat pump when working to provide a cooling effect to the user.

According to the prioritization rules defined in Section 4, the biomass boiler could be used to cover the DHW and space heating demand that could not be satisfied with solar heat and, for some climates, with the heat pump. It was hence considered that it had the same power as the heat pump.

The storage tank was sized based on two main constraints; to avoid overheating and stagnation in the solar collectors and to guarantee at least a daily solar temperature yield. Therefore, its volume was strictly dependent on the size of the solar field. The stagnation temperature could be calculated from Equation (A2) as the temperature at which $\frac{\dot{\mathrm{Q}}}{\mathrm{A}}=0$ [51]:

$$
\mathrm{T}_{\text {stag }}=\frac{\sqrt{\mathrm{Ga}_{0} \mathrm{a}_{2}+\left(\mathrm{a}_{1} / 2\right)^{2}}-\mathrm{a}_{1}}{\mathrm{a}_{2}}+\mathrm{T}_{\mathrm{amb}} .
$$


For the AKOTEC OEM Vario 2400-30 hp collectors and an irradiation of $600 \mathrm{~W} / \mathrm{m}^{2}$, $\mathrm{T}_{\text {stag }}=163{ }^{\circ} \mathrm{C}$. Therefore, the minimum size of the short-term storage allowed keeping the temperature inside the storage below $163^{\circ} \mathrm{C}$ even if for $8 \mathrm{~h}$ irradiation the heat was not used. Considering a maximum allowed temperature of $150^{\circ} \mathrm{C}$ and a maximum energy to be stored equal to the maximum daily solar energy at a certain temperature level $Q_{\max }$, the minimum volume possible for the storage could be calculated as:

$$
\mathrm{V}_{\text {min }}=\frac{\mathrm{Q}_{\text {max }} \mathrm{A}_{\text {coll }}}{\mathrm{C}_{\mathrm{p}_{\text {water }}\left(\mathrm{T}_{\text {stag }}-\mathrm{T}_{\text {sunrise }}\right) \rho_{\text {water }}}}
$$

where $T_{\text {sunrise }}$ is the temperature of the storage after night.

To guarantee a defined solar yield instead, the selection could be based on the average daily demand on DHW because, as seen in the previous sections, this was one of the energy contributions that could be supplied with high solar fractions in different climates and seasons. Correspondently, the target volume of the storage (that needed to be higher than the minimum volume calculated with Equation (A4)), was the volume of water that, at the temperature for DHW, i.e., $60^{\circ} \mathrm{C}$, allowed the storing of the average daily heat for DHW that was produced by the solar collectors. It could be calculated as:

$$
\mathrm{V}_{\text {target }, 1}=\frac{\mathrm{Q}_{\mathrm{DHW}, \mathrm{m}, \text { daily }} \mathrm{A}_{\text {coll }}}{\mathrm{c}_{\mathrm{P}_{\text {water }}\left(\mathrm{T}_{\mathrm{DHW}}-\mathrm{T}_{\text {surrise }}\right) \rho_{\text {water }}}} .
$$

Alternatively, the component could be sized in order to store the daily demand for DHW and heating. Consequently, it corresponded to the volume of water that, at the temperature for DHW (as this is higher than the temperature needed for space heating) could store the average daily production of heat for DHW and space heating from the solar collectors:

$$
\mathrm{V}_{\text {target }, 2}=\frac{\left(\mathrm{Q}_{\mathrm{DHW}, \mathrm{m}, \text { daily }}+\mathrm{Q}_{\text {heating,m,daily }}\right) \mathrm{A}_{\text {coll }}}{\mathrm{c}_{\mathrm{P}_{\text {water }}}\left(\mathrm{T}_{\mathrm{DHW}}-\mathrm{T}_{\text {surrise }}\right) \rho_{\text {water }}} .
$$

\section{References}

1. De la Cruz-Lovera, C.; Perea-Moreno, A.-J.; de la Cruz-Fernández, J.-L.; Alvarez-Bermejo, J.; Manzano-Agugliaro, F. Worldwide Research on Energy Efficiency and Sustainability in Public Buildings. Sustainability 2017, 9, 1294. [CrossRef]

2. European Parliament and Council EU 2018/844 Directive. Available online: https://eur-lex.europa.eu/legal-content/EN/TXT/ ?uri=uriserv\%3AOJ.L_.2018.156.01.0075.01.ENG (accessed on 18 March 2020).

3. European Parliament and Council EU 2018/2002 Directive. Available online: https://eur-lex.europa.eu/legal-content/EN/TXT/ HTML/?uri=CELEX:32018L2002\&from=EN (accessed on 18 March 2020).

4. European Parliament and Council EU 2018/2001 Directive. Available online: https:/ / eur-lex.europa.eu/legal-content/EN/TXT/ HTML/?uri=CELEX:32018L2001\&from=EN (accessed on 18 March 2020).

5. European Commission The European Green Deal—COM(2019) 640. Available online: https://eur-lex.europa.eu/legal-content/ EN/TXT/?uri=CELEX\%3A52019DC0640 (accessed on 18 March 2020).

6. Medina, A.; Cámara, Á.; Monrobel, J.-R. Measuring the Socioeconomic and Environmental Effects of Energy Efficiency Investments for a More Sustainable Spanish Economy. Sustainability 2016, 8, 1039. [CrossRef]

7. Jradi, M.; Riffat, S. Tri-generation systems: Energy policies, prime movers, cooling technologies, configurations and operation strategies. Renew. Sustain. Energy Rev. 2014, 32, 396-415. [CrossRef]

8. Calise, F.; de Notaristefani di Vastogirardi, G.; Dentice d'Accadia, M.; Vicidomini, M. Simulation of polygeneration systems. Energy 2018, 163, 290-337. [CrossRef]

9. Seddiki, M.; Bennadji, A. Multi-criteria evaluation of renewable energy alternatives for electricity generation in a residential building. Renew. Sustain. Energy Rev. 2019, 110, 101-117. [CrossRef]

10. Kim, J.; Jung, Y.; Lee, H. Optimization of dynamic poly-generation system and evaluation of system performance in building application. Energy Convers. Manag. 2019, 201, 112128. [CrossRef]

11. De Boeck, L.; Verbeke, S.; Audenaert, A.; De Mesmaeker, L. Improving the energy performance of residential buildings: A literature review. Renew. Sustain. Energy Rev. 2015, 52, 960-975. [CrossRef]

12. Krstić-Furundžić, A.; Vujošević, M.; Petrovski, A. Energy and environmental performance of the office building facade scenarios. Energy 2019, 183, 437-447. [CrossRef] 
13. Fernandez-Antolin, M.-M.; del Río, J.M.; Costanzo, V.; Nocera, F.; Gonzalez-Lezcano, R.-A. Passive Design Strategies for Residential Buildings in Different Spanish Climate Zones. Sustainability 2019, 11, 4816. [CrossRef]

14. Ballarini, I.; De Luca, G.; Paragamyan, A.; Pellegrino, A.; Corrado, V. Transformation of an Office Building into a Nearly Zero Energy Building (nZEB): Implications for Thermal and Visual Comfort and Energy Performance. Energies 2019, 12, 895. [CrossRef]

15. Pritchard, R.; Kelly, S. Realising Operational Energy Performance in Non-Domestic Buildings: Lessons Learnt from Initiatives Applied in Cambridge. Sustainability 2017, 9, 1345. [CrossRef]

16. Melgar, S.; Bohórquez, M.; Márquez, J. uhuMEB: Design, Construction, and Management Methodology of Minimum Energy Buildings in Subtropical Climates. Energies 2018, 11, 2745. [CrossRef]

17. Park, K.; Kim, S. Utilising Unused Energy Resources for Sustainable Heating and Cooling System in Buildings: A Case Study of Geothermal Energy and Water Sources in a University. Energies 2018, 11, 1836. [CrossRef]

18. Bae, S.; Nam, Y.; da Cunha, I. Economic Solution of the Tri-Generation System Using Photovoltaic-Thermal and Ground Source Heat Pump for Zero Energy Building (ZEB) Realization. Energies 2019, 12, 3304. [CrossRef]

19. Braun, R.; Haag, M.; Stave, J.; Abdelnour, N.; Eicker, U. System design and feasibility of trigeneration systems with hybrid photovoltaic-thermal (PVT) collectors for zero energy office buildings in different climates. Sol. Energy 2020, 196, 39-48. [CrossRef]

20. Mohamed, A.; Hamdy, M.; Hasan, A.; Sirén, K. The performance of small scale multi-generation technologies in achieving cost-optimal and zero-energy office building solutions. Appl. Energy 2015, 152, 94-108. [CrossRef]

21. Palomba, V.; Borri, E.; Charalampidis, A.; Frazzica, A.; Cabeza, L.F.; Karellas, S. Implementation of a solar-biomass system for multi-family houses: Towards 100\% renewable energy utilization. Renew. Energy 2020, 166, 190-209. [CrossRef]

22. Vasta, S.; Palomba, V.; La Rosa, D.; Mittelbach, W. Adsorption-compression cascade cycles: An experimental study. Energy Convers. Manag. 2018, 156, 365-375. [CrossRef]

23. Palomba, V.; Dino, G.E.; Frazzica, A. Coupling Sorption And Compression Chillers In Hybrid Cascade Layout For Efficient Exploitation Of Renewables: Sizing, Design And Optimization. Renew. Energy 2020, 154, 11-28. [CrossRef]

24. Boppe, I.; Bédard, E.; Taillandier, C.; Lecellier, D.; Nantel-Gauvin, M.A.; Villion, M.; Laferrière, C.; Prévost, M. Investigative approach to improve hot water system hydraulics through temperature monitoring to reduce building environmental quality hazard associated to Legionella. Build. Environ. 2016, 108, 230-239. [CrossRef]

25. European Project, ENTRANZE. 2013. Available online: https://www.entranze.eu/ (accessed on 9 February 2021).

26. TRNSYS, A Transient Simulation Program (Version 18) Manual. Available online: https://sel.me.wisc.edu/trnsys/features/ trnsys18_0_updates.pdf (accessed on 9 February 2021).

27. Longo, S.; Palomba, V.; Beccali, M.; Cellura, M.; Vasta, S. Energy balance and life cycle assessment of small size residential solar heating and cooling systems equipped with adsorption chillers. Sol. Energy 2017, 158, 543-558. [CrossRef]

28. Mascuch, J.; Novotny, V.; Vodicka, V.; Spale, J.; Zeleny, Z. Experimental development of a kilowatt-scale biomass fired micro-CHP unit based on ORC with rotary vane expander. Renew. Energy 2018, 147, 2882-2895. [CrossRef]

29. Dai, Y.J.; Hu, H.M.; Ge, T.S.; Wang, R.Z.; Kjellsen, P. Investigation on a mini-CPC hybrid solar thermoelectric generator unit. Renew. Energy 2016, 92, 83-94. [CrossRef]

30. Dipasquale, C.; Fedrizzi, R.; Bellini, A.; D’Antoni, M.; Bales, C.; Gustafsson, M.; Ochs, F.; Dermentzis, G.; Birchall, S. D2. 1c Simulation Results of Reference Buildings. EC FP7 Proj. iNSPiRe Grant Agreem. 2014. Available online: http://dl.icdst.org/pdfs/ files3/383300e7e12c6929c4ba28fb6f20f298.pdf (accessed on 18 March 2020).

31. Birchall, S.; Wallis, I.; Churcher, D.; Pezzutto, S.; Fedrizzi, R.; Causse, E. D2. 1a Survey on the energy needs and architectural features of the EU building stock. EC FP7 Proj. iNSPiRe Grant Agreem. 2014. Available online: https://www.rispostaserramenti. com/wp-content/uploads/2015/02/REPORT_EURAC0.pdf (accessed on 18 March 2020).

32. Action, E. Implementing the Energy Performance of Buildings Directive (EPBD), Featuring Country Reports; EU Publications Office: Luxembourg, 2016.

33. Technical Code: Documento Básico-Ahorro de Energía. 2019. Available online: https://www.codigotecnico.org/pdf/ Documentos/HE/DcmHE.pdf (accessed on 9 February 2021).

34. Finnish regulation: Tasauslaskentaopas 2018. Rakennuksen lämpöhäviön määräystenmukaisuuden osoittaminen (Compensation calculation guide 2018, Demonstration of the heat loss of a building). 2018. Available online: https:/ / www.motiva.fi/ ratkaisut/ energiatodistusneuvonta/energiatodistusten_laatijat/energiatodistusten_laskentaohjeet_2018 (accessed on 9 February 2021).

35. Federal Ministry of Finance and Energy of Germany. Verordnung über Energiesparenden Wärmeschutz und Energiesparende Anlagentechnik bei Gebäuden-Regulation on Energy-Saving Thermal Insulation and Energy-Saving Systems Technology in Buildings (Energy Saving Regulation). 2015. Available online: https:/ /www.bmwi.de/Redaktion/DE/Gesetze/Energie/EnEV. html (accessed on 9 February 2021).

36. Kalogirou, S.A. Chapter five-Solar Water Heating Systems. In Solar Energy Engineering; Academic Press: Boston, MA, USA, 2009; pp. 251-314. ISBN 978-0-12-374501-9.

37. Holma, A.; Leskinen, P.; Myllyviita, T.; Manninen, K.; Sokka, L.; Sinkko, T.; Pasanen, K. Environmental impacts and risks of the national renewable energy targets-A review and a qualitative case study from Finland. Renew. Sustain. Energy Rev. 2018, 82, 1433-1441. [CrossRef]

38. Bórawski, P.; Bełdycka-Bórawska, A.; Szymańska, E.J.; Jankowski, K.J.; Dubis, B.; Dunn, J.W. Development of renewable energy sources market and biofuels in The European Union. J. Clean. Prod. 2019, 228, 467-484. [CrossRef] 
39. Child, M.; Breyer, C. The Role of Energy Storage Solutions in a 100\% Renewable Finnish Energy System. Energy Procedia 2016, 99 , 25-34. [CrossRef]

40. Karthick, K.; Suresh, S.; Hussain, M.M.M.D.; Ali, H.M.; Kumar, C.S.S. Evaluation of solar thermal system configurations for thermoelectric generator applications: A critical review. Sol. Energy 2019, 188, 111-142. [CrossRef]

41. DESTATIS Statistiches Bundesamt. Stromerzeugung im 2. Quartal 2019. Available online: https://www.destatis.de/DE/Presse/ Pressemitteilungen/2019/09/PD19_367_43312.html (accessed on 1 December 2019).

42. Statistics Finland. Production of Electricity and Heat. Available online: https://www.stat.fi/til/salatuo/index_en.html (accessed on 1 December 2019).

43. Red Eléctrica de España National Statistical Series. Available online: https://www.ree.es/en/datos/publications/nationalstatistical-series (accessed on 1 December 2019).

44. Clean Energy for All Europeans Packages. 2019. Available online: https:/ / ec.europa.eu/energy/topics/energy-strategy/cleanenergy-all-europeans_en (accessed on 9 February 2021).

45. Nienborg, B.; Dalibard, A.; Schnabel, L.; Eicker, U. Approaches for the optimized control of solar thermally driven cooling systems. Appl. Energy 2017, 185, 732-744. [CrossRef]

46. Goyal, A.; Staedter, M.A.; Garimella, S. A review of control methodologies for vapor compression and absorption heat pumps. Int. J. Refrig. 2019, 97, 1-20. [CrossRef]

47. Biyik, E.; Kahraman, A. A predictive control strategy for optimal management of peak load, thermal comfort, energy storage and renewables in multi-zone buildings. J. Build. Eng. 2019, 25, 100826. [CrossRef]

48. Duffie, J.A.; Beckman, W.A. Solar Engineering of Thermal Processes; Wiley: Hoboken, NJ, USA, 2013; ISBN 0470873663.

49. Stanciu, C.; Stanciu, D. Optimum tilt angle for flat plate collectors all over the World-A declination dependence formula and comparisons of three solar radiation models. Energy Convers. Manag. 2014, 81, 133-143. [CrossRef]

50. VDI-Wärmeatlas; Springer: Berlin/Heidelberg, Germany, 2002; ISBN 978-3-662-10744-7.

51. Mauthner, F.; Fischer, S. Overheating Prevention and Stagnation Handling in Solar Process Heat Applications. Int. Energy Agency Sol. Heat. Cool. Task 2015, 49. 